Historic, Archive Document

Do not assume content reflects current scientific knowledge, policies, or practices. 



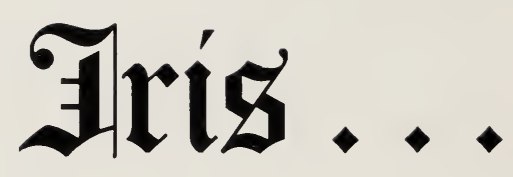

may be planted any

month in the year

but do best when

planted during

June, July, August

and September

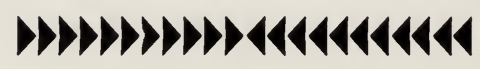

\section{ORDER NOW}

WE HAVE SATISFIED CUSTOMERS IN EVERY STATE 75 per cent of our customers live east of the Mississippi 


\section{KEEEP

A Catalog

of the

Newest and Best

Bearded, Japanese and other

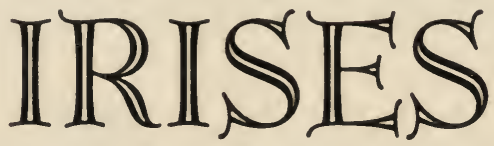

also of

Choice Single,

Japanese and

Double Peonies

1932

NATIONAL IRIS GARDENS 


\section{Iris Information}

\section{Size of Plants}

The rhizome illustrated on the back cover showing ten increases is not unusual. The rhizomes we ship show inereases which are a guarantee of bloom the following year, for without increases, a plant will not flower. We send out good-sized rhizomes but do not guarantee any particular size or number of increases, for the various varieties differ greatly in this respect. Our rhizomes, being larger than those grown in other sections, produce a better flower the first year and multiply more rapidly.

\section{Freedom From Disease}

The Iris Borer and the Japanese Beetle which infest many of the Eastern states are unknown in Oregon. All rhizomes shipped from our gardens are absolutely clean and free from any disease or pests. State horticultural experts who inspect our gardens have never found a trace of injurious pests or disease.

\section{No Irrigation}

We do not irrigate as do some Western grower's. Any complaint made of irrigated plants does not refer to us. Our large rhizomes are a result of fine soil, abundant room, frequent transplanting, and our long growing season. Our large rhizomes DO NOT ROT!

\section{Prices}

Our prices are based on the amount of stock we have of each variety. Although we do not claim to quote the lowest price on each variety, we do elaim that our prices considered as a whole are below average.

\section{Descriptions}

We do not apologize for our short descriptions. We give the essential characteristies and colors of each variety and the price, which is all that any flower lover needs. The lengthy, glowing descriptions used by other Iris specialists in an attempt to make sales is superfluous and may be applied to one variety as well as another. We try to make our descriptions brief and to the point. The letter "S" refers to the standards or upright petals, and the letter "F" refers to the falls or horizontal petals.

\section{Distance We Ship}

Many flower lovers have the mistaken impression that Iris rhizomes eannot be shipped long distances. Practically all of our orders are sent by parcel post and are received in as good condition 3000 miles away as 100 miles distant. We have had repeat orders from Australia and South Africa, in each ease our customers informing us that the rhizomes arrived in perfect condition. A large percentage of our regular customers are situated in the New England and Atlantic states and we have never had a single complaint regarding the state of shipment upon arrival.

\section{Orders}

We prepay all postage on retail orders and ship without delay. We commence shipping immediately after the blooming season. An early order may avoid disappointment as the stock of some varieties is limited. All orders are accepted contingent upon condition and availablity of stock at shipping time. Prompt cash refund for anything we cannot supply. We do not substitute. No orders filled for less than $\$ 1.00$. Cash with order. Remember, our mail address is Beaverton, Oregon. 


\section{Iris Society Ratings}

The figures appearing to the left of the variety name is the rating given by the society and is an aid to the flower lover in making his selection. Those having no figures are more reent introductions and have not as yet been rated. We have discarded all varieties scoring below 80 , as we think there are abundant varieties alove this mark to fill any garden. Varieties rated below this mark are inferior flowers and not worthy of a place in any well-consislered planting.

\section{Stock}

We send out only true to name stock and gladly eorrect any cror made in shipping. We have one of the largest eollections of Iris in the world despite the fact that we have disearded hundreds of inferior varieties and only retain those of reengnized merit. This year we are offering to our customers a choice of nearly four hundred bearded varieties, a select list of Spmria, Siberian, and Miscellaneous Irises, a large collections of Regelia, Regeha-eyelus, and Pogo-evelus hybrids, and the finest collection of correctly named Japanese varieties to be found.

\section{Visitors}

We weleome flower lovers at any season, but especially from May 10 to July 20, during the blooming season. We are located six miles west of Portland on the new Canyon Road, acclaimed as the finest highway leading into Portlind. Our Portland telephone is BRoadway $9747-\mathrm{R}-8$.

\section{Catalog}

We send this catalog free of charge to our regular eustomers and to others requesting it. If you have friends or relatives who are interested in Iris, we shall be glad to forward a catalog to them.

\section{Hardiness}

Our rhizomes are alsolutely hardy. Our winters are not the mild winters of California and many of the Iris that grow well in that state do not thrive with us. Our Iris, however, grow well in that state. Our oceasionally cold snaps strengthens the rhizomes so that no difficulty is eneountered when they are transplanted to colder states.

\section{Testimonials}

Our testimonials come unsolicited. So many of our eustomers have expresset their appreciation of our "Oregon-grown" rhizomes that we feel it only proper to print a few at the top of our eatalog. We have receiverl hundreds of others of similar tone.

\section{Repeat Orders}

The outstanding evidence of satisfied customers is indieated ly repeat orders. Many of our regular eustomers order from us yearly, thus keeping their Iris gardens up-to-date. A few new Iris varieties planted each year add mueh to the flower lover's joy during the lolooming season. We find on examining our reeords that much of our business is repeat orders. We attribute this to the following reasons: (1) Our rhizomes do not rot; (2) our customers run no danger of importing Iris Borer or other pest or disease; (3) our prices are reasonable; (4) our rhizomes are larger than the average; and (5) we carry only the best. 
"I sent you a trial order last year and your plants were fine-much larger than those of other growers."

\section{Special Bargains In Iris}

Realizing that many who desire a selection of Iris may not have the time or inclination to select the proper varieties from our display gardens or catalog, we give below a number of collections which are truly bargains. They have been selected so as to give the most value for the money. One substitution of a variety of similar price may be made in each collection if desired.

All collections are shipped prepaid.

\section{Prize Winning Collection}

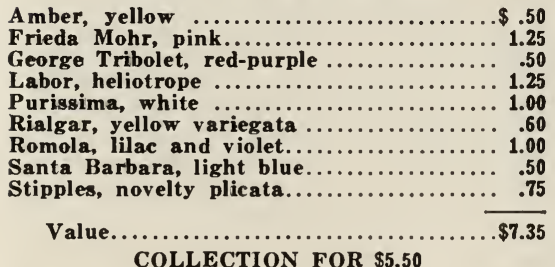

\section{All Pink Collection}

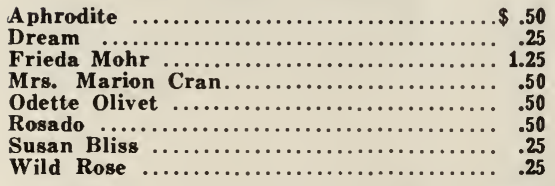

Value....................... $\overline{\$ 4.00}$ COLLECTION PRICE $\$ 3.00$

White Collection

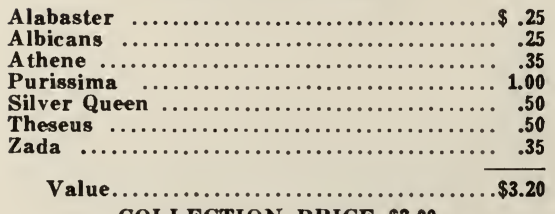
COLLECTION PRICE $\$ 2.00$

\section{Yellow Collection}

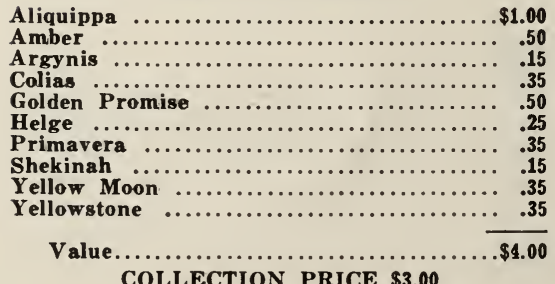

\section{COLLECTION PRICE $\$ 3.00$}

Early Blooming Intermediates

Albicans, white.

Bosniamac, pale yellow.

Carthusian, dark blue.

Fritjof, lavender.

Helge, yellow.

Kochi, claret.

Prince Victor, purple.

Value $\$ 1.75$.

\section{Superb Collection}

A pache, coppery-red .................... $\$ .50$

Chasseur, late yellow........................

High Tide, lavender-yellow................ 3.00

Kestrel, lobelia-violet ................... $\quad .35$

Souv. de Loetitia Michaud, soft blue...... 1.00

Marquisette, shrimp pink................. 3.00

Mt. Royal, red-violet............................ 1.75

Silver Queen, silvery white.............. $\quad .50$

Value........................... $\overline{\$ 10.60}$

\section{COLLECTION FOR $\$ 7.00$}

\section{Mixed Collection}

Centurian, lavender crimson............. $\$ .75$

Hamadan, (pogo-cyclus) lavender......... 1.00

Mme. H. Cayeux, red-violet................ $\quad .50$

Mary Barnett, light blue.................. .50

May Sadler, blue-crimson............... .50

Olive Murrell, lavender-rose ............... .50

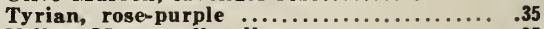

Yellow Moon, tall yellow........................

Value............................ $\$ 4.45$

\section{COLLECTION FOR $\$ 3.00$}

\section{Prize Palestine Iris}

Charon (reg.-cyclus), golden brown.......\$1.50

Hoogiana (regelia), blue ................. 1.50

Stolinifera (regelia), blue-bronze............ 1.50

William Mohr (pogo-cyclus) lilac......... 1.50

Value ........................... $\$ \$ \$ .00$

\section{COLLECTION FOR $\$ 4.00$}

\section{Beginner's Trial Palestines}

Carmelo (pogo-regelia), blue............ .50 Dilkush (pogo-cyclus), red purple............ .75 Hamadan (pogo-cyclus), violet.............. 1.00

Korolkowi (regelia), mixture.............. 1.50

Lady Lilford (pogo-cyclus), purple........... 1.00

Zwannenburg (pogo-cyclus), buff ............. .25

Value............................. $\$ 5.00$

\section{COLLECTION FOR $\$ 3.00$}

\section{Beginner's Japanese Collection}

Ayasi, white with red markings.

Cloud Dress, grey lined purple.

Kombarin, early pure white.

Kuro Kumo, deep purple.

Rishono, red-purple.

Shoryui, white overlaid blue.

Triumph, lavender.

Wakamu, crimson-purple.

Value $\$ 4.00$. 
"The Iris arrived in good condition and were promptly planted. They, certainly bear out your claims for "Oregon-Grown" stock, as they were fine looking rhizomes."

-Eugene Beaudry, Whitinsville, Mass.

\section{TALL BEARDED IRIS}

These are the Iris most generally known and by far the most popular. During May and early June they form a riot of color in an Iris garden.

Aarehorst. S, lilac, blended dark olive; $F$, deep plum violet.......... \$1.00

Aegir. S, pure clear white; F, bright deep crimson. Fine bicolor. . . . . . . 50

88 Aliquippa. A soft yellow, with luminous center. Free in growth........ 1.00

84 Allies. S, deep reddish-violet, tinged copper; F, deep purplish red . . . . 1.25

85 Allure. S, irridescent pink, flushed yellow; $\mathbf{F}$, pink, flushed gold...... 4.00

88 Amber. Deep yellow, prominent reddish-gold beard. Medium height..... .50

Amerind. Metallic Bronze, named from the native Indians. Vigorous... .50

Andante. S, raisin purple with maroon shadings; $F$, same. Vigorous..... 4.00

Antares. S, yellow; F, white, dotted blue. A very different Iris........ $\quad .75$

88 Apache. S, coppery-red; F, dark erimson-brown. An uncommon color..... .50

81 Aphrodite. A large bright violet-pink self. An outstanding pink...... .50

Argos. S, Dauphin's blue; F, velvety petunia-violet, veined brown....... $\quad .75$

Arlette. Cream self with velvety sheen and golden beard and throat..... .50

Arzani. A tall, dark reddish-mauve, well branched and vigorous........ 1.50

84 Asa. S, beautiful cream yellow; $F$, white on yellow ground. Fine....... 1.00

88 Asia. An exquisite blending of silvery lavender and yellow......... .50

89 Asphodel. A large tall, fragrant variety of liglit lavender-violet....... 1.00

83 Athene. A very fine creamy white, giving a good garden effect...... .35

Auburn. S, rose-purple, flushed ochre-red; F, warm crimson. Very good... .50

Aurifero. Two shades of lavender, flushed rose. Rich go'd heard....... .50

Avatar. A smoky-purple blend with standards suffused with gold ........ .75

84 Azrael. Early flower of two shades of violet with orange heard ....... . 35

Azyiade. S, sky-blue; F, soft bluish-mauve. One of the largest....... 1.25

Baldwin. An outstanding manganese-violet self, tall and well-branched... 2.50

85 Bandollero. Distinetive light blue, beautifully veined. One of the best... $\quad .50$

Batulus. S, bright purple- rose; $\mathrm{F}$, a beautiful rose-crimson.......... $\quad .35$

80 Belisaire. S, light tan, suffused rose; F, erimson-madder. Exquisite..... $\quad .75$

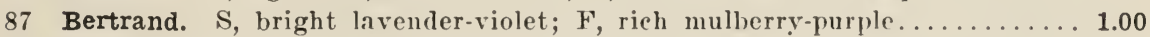

Bluebonnet. S, delicate chicory blue; $F$, deep purple-violet. . . . . . . 3.00

90 Bruno. $\mathrm{S}$, fawn and bronze; $\mathrm{F}$, deep, rich velvety red-purple. Late..... 1.25

Buto. A large, rich, velvety, deep royal purple. Satiny texture......... 1.50

Camilla Dubuar. A beautiful pink with many blossoms to a stalk....... 2.50

91 Candlelight. A delieate blend of pinkish lavender with yellow......... 1.50

Canyon Mists. A deliglitful soft mauve self and very outstanding....... .35

90 Cardinal. S, lavender; F, dark red-purple. A truly wonderful bloom...... 2.00

83 Caroline E. Stringer. This is the lightest pink toned Iris grown . . . . . . .75

Cassiopee. S, broad, ageratum blue; F, Dauphin's blue, edged gray...... $\quad .75$

86 Centurion. Large flowers with $\mathrm{S}$ light lavender and $\mathrm{F}$ velvety erimson.... $\quad .75$

85 Chasseur. A very fine, late yellow with broad standards and rounded $\mathrm{F} \ldots .50$

Cinnabar. S, violet-purple; $\mathrm{F}$, cotinga-purple. An excellent flower....... 1.75

85 Citronella. A clear yellow, the $\mathrm{F}$ heavily washed with chestnut........ .50

Cockatoo. A soft, elear yellow plicata which is very distinctive........ 3.00

82 Colias. A straw yellow flower of very good height............. 35

85 Conchobar. S, light purple; $F$, velvety deep reddish-purple. Large...... . .50

85 Conquistador. Deep mauve shading to light lavender. Tall and fragrant.. $\quad .35$

Cooley Surprise. One of the finest large medium blue selfs. Tall..... 3.50

Coppersmith. S, crimson-purple; F, coppery-red. Long lasting......... 2.25 
"Your Iris arrived and in the seven years that I have been buying Iris, I have never seen larger rhizomes. If these roots are a sample, you have a customer for life."

-Mrs. S. W. Holden, Petersburg, Va.

80 Cornault. S, lavender, shaded buff; F, erimson. Orange-yellow beard.... $\$ .50$ Coronation. A clear, deep golden yellow. One of the most desirable..... 2.50

83 Crimson Glow. A uniform shade of brilliant crimson, tinted rose...... . .35 Cottage White. A pure white of medium height. Very floriferous........ 1.00

83 Delight. White-rose plicata with orange beard. Award of Merit, 1928 ... $\quad .50$

91 Dolly Madison. Mauvette, shaded yellow. F, flaring, lilac, tinged gold... 1.75

Don Quixote. S, deep lavender and yelow; hyssop violet. Very good..... .50

Dr. C. H. Mayo. One of the finest real pink Irises yet introduced....... 1.00

Duchess Sarah. S, bright violet; F, rich bluish-violet. Large.......... 1.50

87 Duke of Bedford. Rich, deep violet-purple with orange beard. Vigorous... .60

Elaine. A delightful yellow and violet blend with silken sheen......... 1.00

81 Elberon. S, red-purple; F, deeper. A new, distinct shade of red........ .35

87 El Capitan. A manganese violet bicolor of great beauty. Briglit beard... 1.00

Elizabeth Egelberg. Beautiful blending of pink and mauve. S, dome shaped. 4.00

Elsinore. A beautiful soft primrose yellow bordered with purple........ 1.75

84 Ember. A fine rich violet-red self, with brilliant orange beard........ .60

Endymion. A soft creamy-yellow, with lilac flush. Much admired...... $\quad .75$

Ensorecleur. White, stippled and striped lilac, giving unique effect...... 1.00

Etoile Du Matin. Sulphur yellow, the $\mathrm{S}$ dotted brown, $\mathrm{F}$ blue.......... 1.00

Euphemia. S, cotinga purple; F, prune purple to black. Very tall ....... 2.50

Evadne. A beautiful warm and glowing rose-red. Very fragrant........ . 35

Eventide. A very beautiful and distinetive soft lilac self.......... .75

81 Fidelio. S, metallic blue; F, elear violet. Fine large flowers......... .50

Firefall. One of the brightest red Irises grown in our gardens......... $\quad .75$

Fire God. S, red-bronze, tinged lavender; F, brown garnet. Early........ 1.50

84 Folkwang. S, white; F, elaret red. An interesting color combination..... .50

Fortuna. S, elear amber yellow; F, yellow, lined red-brown.......... 1.00

Fra Angelico. S, light golden bronze; F, deeper, with rich gold beard.... 1.25

85 Frieda Mohr. S, lilac-pink; F, lilac-rose. Large and free-flowering...... 1.25

87 Gabriel. S, bright, elear steel-blue; F, bright violet-blue. Tall. . . . . . 1.50

Gamalia. S, dark violet; $F$, rich dark red-purple, flushed amber......... 2.00

Gaulois. S, golden yellow suffused bronzy-rose; F, bordeaux red........ $\quad .75$

Gay Hussar. S, lemon-chrome; F, velvety ox-blood red. Fine variegata.... 1.00

88 George J. Tribolet. S, violet; F, velvety red-purple. Coppery suffusion... .50

90 Germaine Perthuis. Intense velvety violet-purple self. Fragrant....... 1.25

86 Glamour. S, heliotrope, tinged pale ochre-yellow; F, rich, red-violet..... 1.00

Gloriae. Light blue self of great size, giving wonderful garden effect..... 1.00

86 Glowing Embers. S, a warm tan slightly flushed violet; F, glowing red.... $\quad .50$

Golden Glory. A fine blending of yellow and eream. Late flowering..... 1.25

81 Golden Promise. S, citron-yellow; F, chrome-yellow. A fine variety ....... .50

87 Gold Imperial. A fine chrome-yellow self with conspicuous orange beard... .50

Grandiosa. S, raisin-lilac; F, dark blue-purple. A giant L. Williamson..... 4.00

Grenadier. Large flowers with violet-purple $\mathrm{S}$ and darker falls. Tall..... 1.00

Grisette. S, walnut. brown, shot with violet; F, slightly lighter......... 1.00

Grousman Red. A brilliant cardinal tone which is extremely attractive... 1.75

Havamal. $S$, eream flushed lilac; $F$, violet-blue with eream border....... $\quad .75$

87 Hidalgo. A tall, large lavender self, giving a soft pink effect in mass..... .35

High Tide. Soft dark lavender with yellow edge on F. A superior Asia... 3.00

Horizon. A uniform light blue which is especially attractive in mass...... 1.00

84 Imperator. S, light red; F, deep velvety rose red. Quite large......... . .35

Impressario. S, lobelia-violet; F, purple. A beautiful blended bicolor..... $\quad .50$ 
"I received the Iris in fine condition. You surely grow extraordinarily fine plants-the best I ever saw. Any of my friends inquiring about Iris will certainly be referred to you, hereafter."

-Frank Emory, McClellandtown, Pa.

Jane Williamson. S, vinaccous lilac; $\mathrm{F}$, deeper. Gives pink pastel effect.... $\$ 1.50$

Joya. A very deep blue self of fine form and substance............ 2.00

Jubilee. S, satiny, tinted a rich peach color; F, cream, veined brown..... .50

85 Julia Marlowe. A marvelous g'owing pink and red. Tall and fragrant... .50

June Night. A much deeper, darker colored sensation. Very large flower. . 5.00

Kansas. A beautiful, tall, ruffled lavender pink, blooming quite late..... 3.00

Karen. A very deep rich red-purple variety with flaring falls......... .35

Katherine McFarland. S, mullerry purple; F, beautiful rich purple..... 3.50

84 Kestrel. A blending of rich lobelia and velvety, violet tones. Rich..... .50

83 King Karl. A large creamy white, sanded rose, Similar to Lona....... 1.00

King Tut. S, brown with a strong red suffusion; F, glowing red........ 2.50

La Bohemienne. Deep helibore red flushed with bronze. Unusual color... 1.00

87 Labor. A distinct violet. heliotrope with S suffused with coppery glow ... 1.25

Lady Bountiful. A fine tall beautiful c'ear blue which is much admired.... .50

Lady Sackville. S, pale silvery blue; $\mathrm{F}$, rich violet-purple. Large....... .75

Le Correge. S, bronze, suffused with violet; F, wine red, brilliant beard... 2.00

83 Le Grande Ferre. S, fawn gray, tinted pink; F, shaded and edged fawn... $\quad .50$

Lenz-Chnee. A fine pure white, slightly flushed with lavender......... 1.00

88 Leonato. A large lavender blue flower of exeeptional beauty. Fragrant... .50

82 Leverrier. S, distinctive mauve; F, velvety elear, rich pansy-violet..... . .35

83 Lona. Soft buff, sanded with purple. Resembles a fine orehid........ .50

8.5 Lord Lambourne. Rose-buff, suffused pale bronze; F, rich madder-red..... . .50

Los Angeles. Great white flowers with $\mathrm{S}$ faintly edged pale blue ....... 3.50

Lustre. A very early reddish-lavender of good form and substance...... .50

Magenta. Deep amethyst violet, a new eolor for Iris. Fine flower...... 5.00

Magnificent. S, bright violet-rose; $\mathrm{F}$, erimson, large and long........ .60

88 Majestic. S, bluish-mauve, flushed bronze; F', rich raisin-purple........ .35

Marquisette. Shrimp-pink-an entirely new break in eolor for Iris....... 3.00

Marsouin. S, pale violet; F, rich violet-purple. Late flowering......... 1.00

90 Mary Barnett. Exquisite light blue self, a brilliant golden beard........ .50

8.) Mary Gibson. S, overlaid with old rose; $\mathrm{F}$, old rose $\ldots \ldots \ldots \ldots \ldots \ldots \ldots . .35$

81 May Sadler. S, violet blue; F, madder-erimson, with dark bronze beard... . 50

Messaline. S, pale gold, flushed pink; F, red, shading to gold.......... 2.50

83 Mestor. S, lroad, of light violet-blue; $F$, rich violet-purple......... .50

Midgard. An indescribable soft pink, slightly flushed with yellow...... 2.50

86 Mildred Presby. S, warm ivory white, flushed pale rose; F, dark violet... . .35

Mme. Cecile Bouscant. S, elear orehid pink; F, violet, suffused rose..... 1.00

86 Mme. Chatenay. S, rose-ash color; $\mathrm{F}$, old rose, with white throat....... .35

89 Mme. Durrand. Irideseent buff, heautifully flushed lilae and amber..... .75

85 Mme. Henri Cayeux. S, smoky red-violet; F, velvety dark erimson...... . .50

87 Moa. Enormous violet flowers on tall, well-branched stalks.......... 1.00 
84 Moonlight. Very early white flushed yellow and palest lavender.......\$.75 Mount Royal. S, deep blue; F, red-violet. Large and very fragrant...... 1.75 Mrs. Iltis. A large, late, wistaria blue of fairly good height......... 3.00 Mrs. Marion Cran. An unusual shade of brilliant light rose and pink..... $\quad .50$ Nebraska. Attractive Apricot yellow, the F striped and clouded brown.... 2.50 Odenvogel. S, bright citron-yellow; F, purple-violet. Very good........ $\quad .50$ Odette Olivet. An early soft orchid-pink, competing with the best...... .50

84 Olive Murrell. S, deep lavender rose, shaded bronze; F, lavender blue..... $\quad .50$

83 Olympus. S, rose, overlaid with bronze; F, madder-crimson, edged yellow. . .50 Omaha. A large flower with soft rose $\mathrm{S}$ and old Rose F. Rich beard...... 1.50 87 Ophelia. Pink, blended with orange. A distinct and novel combination... 2.00

84 Oread. Brilliant bronze and erimson of fine texture. Large and early..... 1.00 Orion. S, smoky violet with plush-like velvety black-violet falls......... 1.50 Ortrud. An early short red blend, many flowers to a stalk.......... 3.00 Peach Blow. An unusual soft peach tinted blend. A beautiful flower..... $\quad .35$

89 Peerless. A large flower giving an effect of rich, glowing mahogany-red.. 2.75

90 Petruchio. S, lobelia violet; F, dahlia carmine. Fine gold beard....... 2.75

90 Pioneer. A brilliant red-purple self and one of the finest in its e'ass..... $\quad .50$

82 Primavera. A fragrant, soft primrose yellow self. Very early......... . 35

88 Primrose. One of the most desirable deep, clear yellow varieties........ .60

95 Purissima. The largest and finest pure white. Very floriferous........ 1.00

80 Rene Cayeux. A very large and late white bicolor with $\mathbf{F}$ crimson-violet... $\quad .75$ Rhea. A blend of mauve and gold creating an exquisite combination..... $\mathbf{1 . 5 0}$

87 Rheingauperle. A beautiful soft rose-very pink in certain lights....... .75

82 Rialgar. A fine yellow chrome variegata with $\mathrm{F}$ veined and flushed red... $\quad .60$

83 Robert Wallace. A fragrant rich dark violet and purple black. Fine.... .50

89 Romola. S, pale lilac tinged ivory at base; $\mathrm{F}$, velvety red-violet...... 1.00

Rosado. A most beautiful clear soft pink, ranking among the very best... $\quad .50$

88 San Francisco. Large white, much lined lavender edges. Finest plicata... 3.00 San Luis Rey. S, red-purple; F, purple-violet. Rich orange beard....... 1.75

89 Santa Barbara. Pure lavender blue, the finest of its color; F, flaring.... $\quad .50$

Senorita. Pale lavender blue, overlaid with luminous yellow. A fine pastel. $\mathbf{. 5 0}$

Sensation. A large, beautiful clear blue self which has been well named... 4.50

Sikh. A rich bronzy purple blend, similar to Bruno but more coppery.... 3.25

Silver Queen. An early attractive silvery white, palest yellow throat..... $\quad .50$

84 Sir Galahad. A fine mauve and pansy violet tinged with red. Large..... $\quad .50$

Sir Michael. Unquestionably the finest blue and purple bicolor in world. 5.00 Skitchewaug. S, silvery rose, flushed bronze; F, mauve, shot with gold... 1.25

85 Solferino. A bright red-lilac brightening to brilliant pink-violet....... $\quad .75$

Sophie. A tall self of manganese-violet, suffused with bronze......... 1.00

Sophronia. A large pure white greatly enhanced by a rich orange beard... $\quad .75$

Sorcerer. A large distinct blue bicolor, very late in blooming......... 1.50

88 Souv. Mme. Gaudichau. The best early dark purple at a low price...... . 35 
90 Souv. Loetitia Michaud. A lovely soft blue, very large and beautiful..... $\$ 1.00$ Stipples. White with blue stipplings and dots. A pleasing novelty plicata.. $\quad .75$ Sunbeam. A new, early, clear yellow from England. Vigorous grower.... 1.75

84 Swazi. S, blue-violet; F, dark pansy-violet. A beautiful late Iris...... 1.75 Thais. An attractive shade of rosy mauve and soft pink, nearly a self ..... 1.25

82 Titan. S, violet-blue; F, violet-purple. Truly enormous flowers....... .50 Trostringer. A vigorous and free flowering light rose-purple self ....... $\quad .75$ Troyon. S, old gold, sharled red-browu; F, lieliotrope, elged gold ....... 1.00 Tuscany Gold. A distinet reddish gold with $\mathrm{S}$ lighter yellow.......... 4.50

85 27th Avril. S, violet-purple; F, velvety with a more bluish tint...... .35

88 Tyrian. Violet and rose-purp'e, giving a vivid deep claret effect...... . .35 Uncle Remus. Velvety deep mulberry self. Early and distinctive....... 1.00

85 Valencia. A beautiful bright orange-buff self. Distinct and unusual..... .35

89 Vesper Gold. Shades of old gold and soft apricot-yellow interming'ed..... 1.00

Watteau. S, campanula violet; $\mathrm{F}$, violet-purple. An unusual variety.... .35

87 Wedgwood. One of the finest rich blue selfs, with striking white heard... $\quad .50$ White and Gold. A large, fine white, enhancerl with a bright gold beard... $\quad .75$ William Mohr. Most remarkable hybrid produced. Lilac ground, veined violet. (See page 23 for other pogo-eyelus varieties)............. 1.50

85 Yellow Moon. A beautiful yellow self, taller than most yellows........ $\quad .35$

83 Yellowstone. S, straw yellow; F, pansy purple. A contrasting bicolor..... .35

81 Zada. An absolutely pure white of perfect shape. Extremely hardy ...... . .35

Entire collection, valued at $\$ 243.10$, for $\$ 200.00$

This offer is a wonderful bargain for flower lovers, Iris collectors, dealers, and persous thinking of entering the Iris business.

Only varieties scoring above 80 are listedvarieties of recognized merit.

\section{INTERMEDIATE IRIS}

These Iris average fifteen inches in height and bloom two to three weeks before the tall beared varieties. By all means, add a few to your garden.

Albicans. Pure white throughout. Good flower.................... $\$ 0.25$

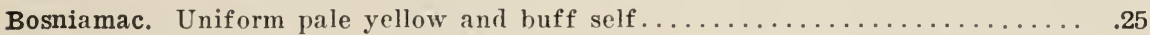

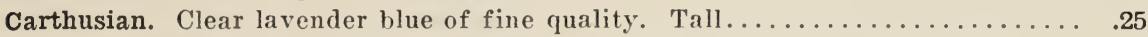

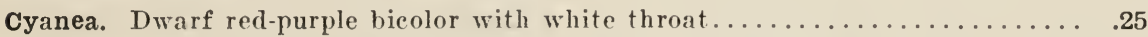

Don Carlos. S, blue; F, red-purple. A different flower............... .

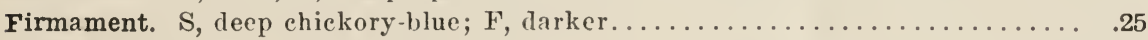

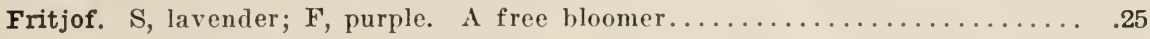

Helge. Lemon-yellow with pearly sharling. Good color blending ........... .25

Ingeborg. Gigantic white with golden veining and beard $\ldots \ldots \ldots \ldots \ldots \ldots \ldots .25$

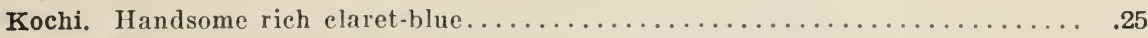

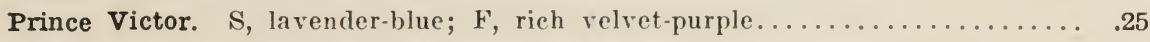

Soledad. A vigorous free flowering, pure yellow self . . . . . . . . 50

Sunbeam. A new, clear yellow from England, of vigorous growth......... 1.75

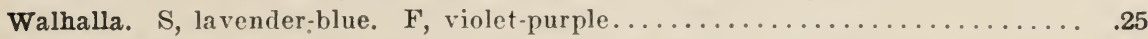

Yellow Hammer. A large, bright amber yellow, sweetly scented...........25

Zua. Frosted white, washed with gray. Charmingly ruffled at edges....... . 25

Zwannenburg. A large buff colored Pogo-cyclus hybrid. Very early......... .25 
"Thanks for the fine Iris sent. I noticed when I received your catalog that you had only those rated above 80 . Also that your prices were very reasonable as compared with our California growers."

\section{5c Each}

In keeping with our policy of offering the best Iris for the least money, we are offering these fine varieties at this exceptionally low price. Just a few years ago, we sold these plants at prices ranging from $\$ 2$ to $\$ 10$. When our stock has been completely exhausted, we shall be forced to return any orders received for we ourselves cannot purchase many of these varieties at wholesale for the price we are offering them to our customers.

Alabaster. Early, pure white.

Anne Bullen. Blue and purple.

Arlington. Lavender and purple.

Armand Clavaud. Violet on yellow.

Avalon. Satiny pink lavender.

Baldur. S, buff; F, maroon.

Ballerine. Fragrant violet-blue.

Bandollero. Distinctive blue.

Canopus. S, lavender; F, violet.

Cassandra. Rosy-violet and red.

Claridad. Beautiful clear blue.

Dream. Fragrant, rose-pink.

Duke of York. Very fine blue.

Dulcinea. S, lav.; F, violet-blue.

Esplendido. Red-purple bicolor.

Fismes. S, cream; F, red-lavender.

Gaviota. Cream, edged yellow.

Harriet Presby. Petunia-violet.

Hesperia. Maroon-purple blend.

Hippolyta. Fine lavender-blue.
Jacqueline Guillot. Silvery blue.

Magnifica. Huge red-violet.

Montserrat. Lavender and purple.

Morning Splendor. Dark ruby-crimson.

Mrs. Cuthbertson. Rose and apricot.

Mrs. H. Matson. S, bronze; F, purple.

Mrs. H. F. Bowles. Brown and red.

Odaroloc. Luminous orehid.

Prospero. Blue and red-purple.

Proteus. Large, silky blue.

Seminole. A very fine red.

Silverado. Late, silvery blend.

Simone Vaissiere. S, white; F, blue.

Susan Bliss. Soft rose.

Tenebrae. Rich black-purple.

Tropic Seas. Vio'et-purple.

True Charm. Fine white plicata.

Veloute. Deep blue bicolor.

Wild Rose. Soft satiny pink.

Yolande. Large, beautiful blue.

Collection of 38 , valued at $\$ 9.50$, for $\$ 7.50$

Just check varieties desired and tear out sheet. 
Name

Street

Post Office

State

Quantity Names of Plants Wanted

Please send your catalog to the following Iris loving friend:

Name

Address 
"I am certainly proud of the fine large Iris rhizomes you sent me this season. They are the largest and finest I have ever seen."

\section{5cilEach}

These are Iris of earlier introduction of which we have built up a sufficient stock to offer at such an attractive price. They are very fine in mass and are excellent varieties to start the Iris planting. After these have bloomed in the beginner's garden, the flower lover will wish to add some of the newer originations offered in our general list. Many of the varieties listed here are priced by other growers at from three to five times our figure.

Afterglow. Blend of buff.

Alcazar. S, mauve; F, purple.

Ambassadeur. S, smoky; F, blackish.

Andree Autissier. Pale lilac-blue.

Argynnis. S, yellow; F, brown.

Aristocrat. S, pink; F, lavender.

Azulado. Lustrous pearl gray.

Bernard Galloway. Red-purple self.

Bravura. Tall, deep rosy-lilac.

B. Y. Morrison. Lavender-violet.

Chaber. Early, blue-violet.

Cluny. Pale lilac-blue.

Coronado. Lavender and purple.

Corrida. Fine blue-violet self.

Cypriana. Two shades of violet.

Dryade. A fine violet bicolor.

Eden Philpotts. Dark blue.

Ed. Michel. Petunia-violet self.

Ensign. Lobelia and petunia-violet.

Fenton. Light lavender-blue.

Halo. S, dark blue; F, violet.
Heart of Gold. Blue-yellow blend.

Isoline. Silvery rose and mauve.

Jeannett Dean. Blue-lavender.

Juniata. Clear violet-blue.

Lent Williamson. Lavender-pansy.

Lepinoux. Blue-purple bicolor.

Margery. Two shades of violet.

Marsh Marigold. Yellow bicolor.

Mary Orth. Velvety blue-violet.

Mme. Cheri. Violet and pink.

Mme. Chobault. Yellow and brown.

Mlle. Schwartz. Large pure mauve.

Mrs. Charles Pearson. Early mauve.

Nine Wells. Lavender-violet.

Rhein Nixe. S, white; F, violet.

Shekinah. Tall light yellow.

Sindjkha. Lavender and buff.

Sweet Lavender. Violet-purple.

Vincentio. Red-purple bicolor.

W. C. Terry. S, blue; F, red-purple.

Yeoman. Blue-violet bicolor.

Collection of 40 varieties, valued $\$ 6.00$, for $\$ 5.00$

Just check varieties desired and tear out sheet 
"I received the Iris you sent and wish to state that they were in perfect condition and were wonderful rhizomes."

\section{AYRES INTRODUCTIONS}

These originations of Dr. W. M. Ayres of Cincinnati are so outstanding that thay have attracted national notice.

Indian Chief. F, velvety, deep blood red; S, considerably lighter in tone. A tall, well-branched, superior red carrying a bronzy overeast...........\$6.00

Jacquard. A distinct shade of red. S, dark vinous mauve; F, velvety violet

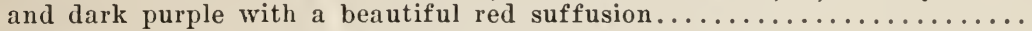

Meldoric. Rated the second best 1930 introduction. Flowers blue-black, of large

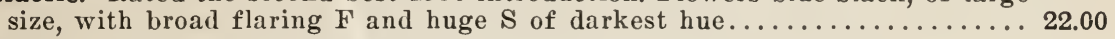

Persia. S, smoky blue, flushed lavender at edge; F, vivid intense blue....... 20.00

Red Dominion. A particularly striking red dominion which has attracted much attention in the Ayres garden during recent years................... 25.00

Tapestry. A subtle blend of monster size, smoky mulberry in general color effect, passing out to smoky tones of $\mathrm{S}$. Dominant note is dull red........ 10.00

Venus de Milo. Absolutely clear white, of a warm ereamy tone, with a yellow beard. Dominion blood makes it very hardy. A very large flower....... 10.00

Zuni. A very early glowing red-brown, overlaid with copper. $\mathrm{F}$ are a brilliant red with sun's ray on them, and S seem sprinkled with gold-dust......... 10.00

Entire collection, valued at $\$ 108.00$, for $\$ 90.00$

\section{KIRKLAND INTRODUCTIONS}

These varieties were originated by Dr. J. K. Kirkland, Chancellor of Vanderbilt University at Nashville, Tennessee. The originator is an Iris enthusiast who is making Nashville "The Iris City." These introductions place him in the forefront among American Iris hybridizers.

Andrew Jackson. A rich red-violet, large in size, with many flowers.......\$ 5.00

Black Wings. A very dark flower, almost black in color, but attractive..... 25.00

Blue Banner. Brilliant clear electric blue which has proved a favorite..... 5.00

Desert Gold. Rated by experts as third best 1930 introduction. A very large,

early medium yellow, being neither deep nor pale. Deeper yellow beard.. 10.00

Hermitage. A very beautiful red blend awarded H. M., A. I. S. in 1930 .... 25.00

Mary Elizabeth. Brilliant rosy-red S, with darker and more velvety F...... 20.00

Morning Glory. A fine, large red-violet, superior to Morning Splendor....... $\mathbf{1 5 . 0 0}$

Summer Cloud. A beautiful attractive blue, distinct from other blues...... 15.00

Entire collection, valued at $\$ 120.00$, for $\$ 100.00$

\section{MISCELLANEOUS IRIS}

Stylosa Speciosa (Unguicularis). This is our Winter bloomer which blooms from the first of December until April. The flowers are of a light lavender color and the plants have a grass-like foliage. Not extremely hardy in the colder sections although it is grown successfully in Connecticut and some of the

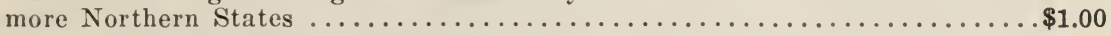

Cacique. A unique flower of prune and black-purple, with a livid signal-pateh

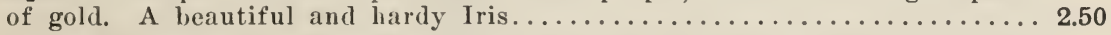

Dorothea Williamson. An American hybrid of a royal purple. Entirely different from others and fine for table bouquets........................40

Fulvala. Similar to the two above but more copper in tone. Very fine..... .75

Pseudacorus Gigantea. An improved form and much larger than the common Pseudacorus, known as the "Yellow Water Iris." The flowers are of pure yellow, the plants growing in marsh or swampy land, in water, or in dry soil.

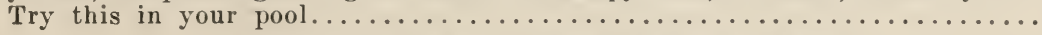


"Herewith is my second order for Iris from your garden. I think so highly of your plants that this year I am purchasing from no other grower." -Glenn Hopper, Fort Wayne, Ind.

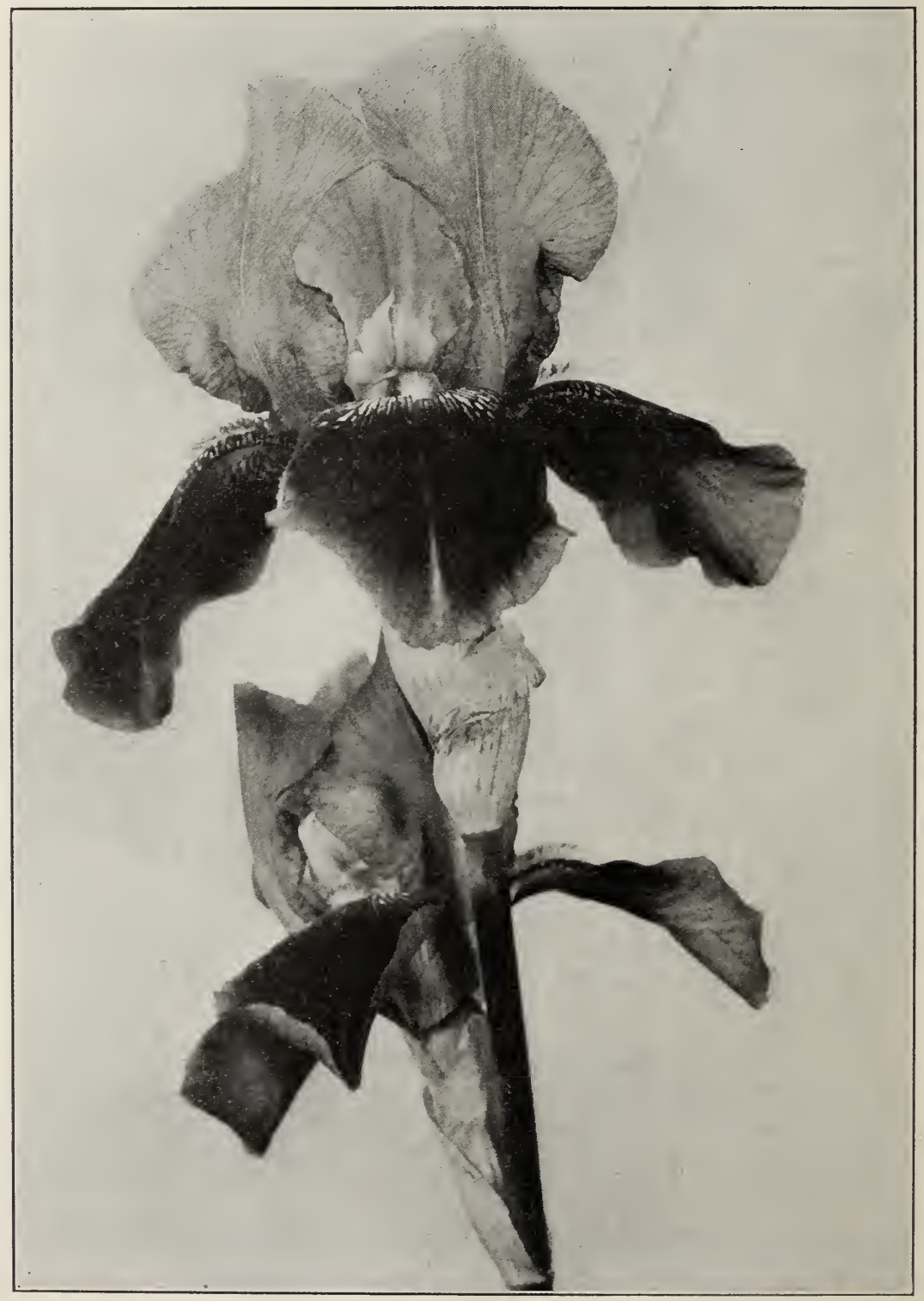

OREGON BEAUTY

$A$ rare and beautiful recent introduction. 


\section{FAMOUS WAREHAM SEEDLINGS}

For a number of years the marvelous seedlings of John D. Wareham, grown on the estate of Mrs. Samuel Taft in Cincinnati, lave been admired and discussed. Not until last year were the originator's friends able to convinee him that it was his duty to make these beautiful varieties available to flower lovers. We are one of the few large firms selected to distribute them this season. The five varicties listed here represent the best in their respective color elasses and were chosen from the thousands of seedlings grown.

Alchemy. Deep yellow blossoms, heavy of texture and wonderful in form, borne on tall, well-branched stems. Acelaimed the finest yellow produced. .\$42.00

Eothen. Soft, ivory-yellow, entirely overlaid buff, produeing an effect of rich antique ivory. Large blooms, freely produced make it a favorite....... 25.00

Legend. Huge, erimson-claret flowers, competing with our finest reds . . . . 12.50

Mabel Taft. A giant violet-blue of the famous Dominion race, invariably selected by visitors as one of the originator's outstanding varieties........ 12.50

Tiger-Tiger. A distinctive name for a distinctive Iris. A brilliant large red Iris of a shade entirely distinct from the renowned Dauntless . . . . . . . 19.00

Entire collection, valued at $\$ 111.00$, for $\$ 100.00$

\section{ox}

\section{OREGON ORIGINATIONS}

Not all the fine recent introductions have been produced in California, Nehraska and Europe as any flower lover ean testify who has seen the following varieties in bloom.

Crown Prince (Kleinsorge, 1931). S, solid deep orange-yellow; F, solid relvety brownish-red. This giant variegata has every desirable characteristic . . . \$ \$30.00

High Tide (Barber, 1930). S, blue lavender; F, darker and flaring, with base light colored with a yellow edge. Resembles Asia but is far superior....

Klamath (Kleinsorge, 1929). Subtle blending of browu and bronze on a purple ground. A very rich, large flower of fine form and substance.......... 15.00

Oregon Beauty (Kleinsorge, 1930). A fine flower, being a blend of acomteviolet, cotinga-purple, and coppery-rose. Flaring $\mathrm{F}$ with yellow beard.... 15.00

Oregon Giant (Kleinsorge). A rery large flower with $\mathrm{S}$ red-purple and $\mathrm{F}$ hlack, velvety purple. One of the darkest Iris but rich appearing ........... 10.00

Surprise (Cooley, 1928). A beautiful, large, tall medium blue suffused heliotrope. The intense burnt-orange beard is an outstanding feature......... 
"Iris came this afternoon-such fine plants and fine value. It is a pleasure to occasionally get more and better things than you expect."

-Mrs. V. P. Brown, San Antonio, Texas.

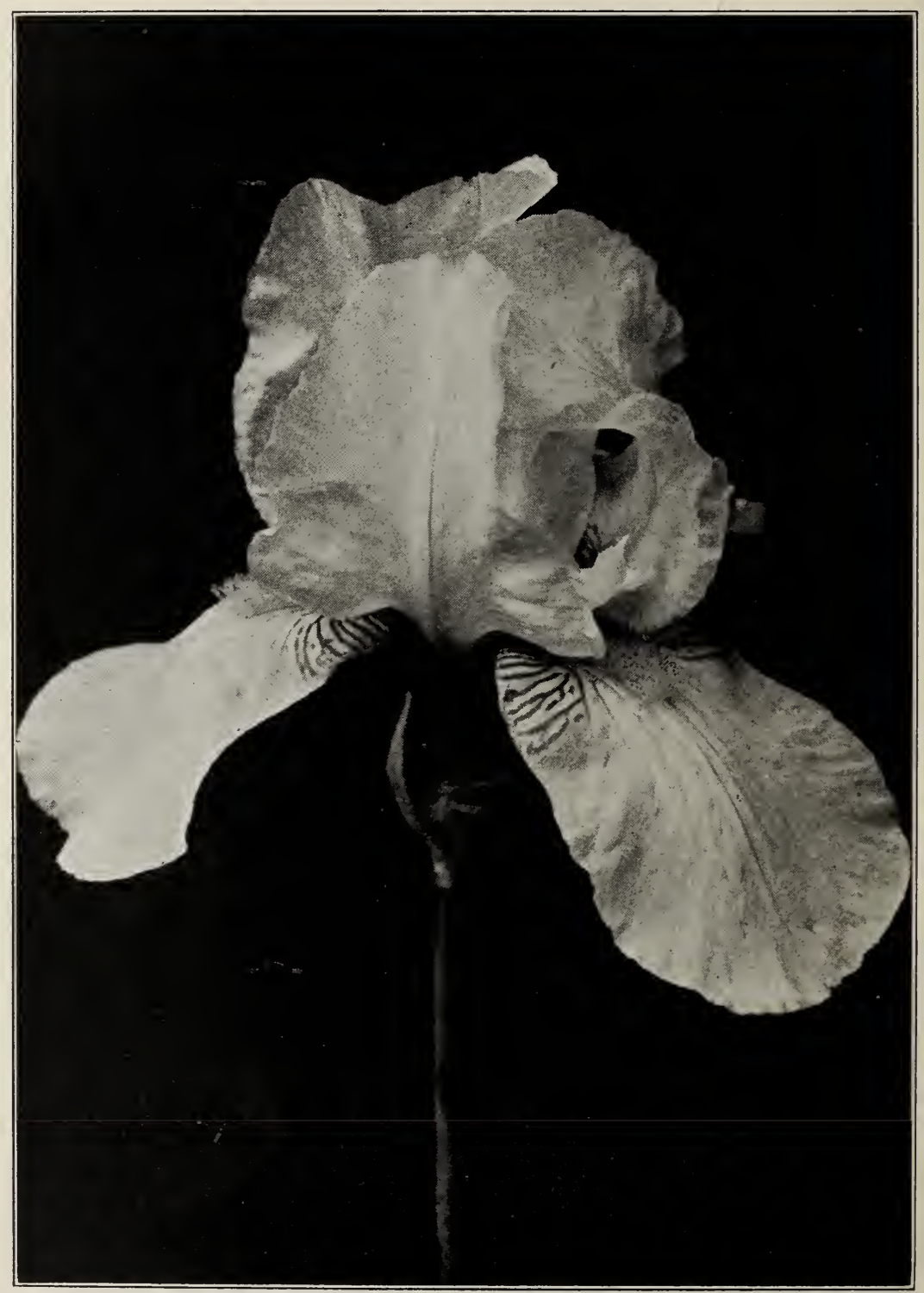

WAMBLISKA

The finest hardy white origination. 
"The Iris arrived yesterday and I can very truthfully say that the rhizomes are the finest $I$ have ever received. More surprising than the quality was the excellent condition of the root systemthere was not the slightest sign of drying. From all appearances these rhizomes might have been sent to me from nearby Virginia rather than from all the way across the continent."

- Charles W. Ayars, Tacoma Park, D. C.

\section{NEW INTRODUCTIONS OF MERIT}

Because these varieties are of comparatively recent origination thus making the prices higher, we are listing them in this special section for convenience to our customers.

Blue Velvet (Loomis, 1929). A rich, beautiful, very dark blue.......... $\$ 20.00$

Boadicea (Nich., 1931). Soft apricot blend with pinkish lights......... 5.00

Beau Sabreur (Wmsn., 1930). S, orange-yellow; F, red-brown. Rich variegata. 4.00

Clara Noyes (H. Sass, 1930). Warm blend of peach and apricot. See coiver... 9.00

Carfax (Bliss, 1929). Tall intensely rich red-purple. Silver medal winner.... 15.00

Classic (Grinter, 1930). Great improvement over Asia. A distinctive type... 22.00

Dauntless (Connell, 1929). Acclaimed to be the finest red yet introduced.... 9.50

Don Juan Cayeux (Cayeux, 1927). S, light rosy-lilac; F, bright red......... 15.00

Depute Nomblot (Cayeux, 1929). S, rosy-purple; F, garnet-red. World's best..28.00

Doxa (H. Sass, 1929). Gigantic creamy white flushed soft yellow and green. . 4.00

Enchantment (Cay., 1928). S, lilac and fawn; F, purple-red and garnet..... 7.50

Erin (Mor., 1930). S, light lavender; F, petunia-violet. Tall and large.... 5.00

Euphony (H. Sass, 1929). S, ruffled copper; F, violet tinged. See cover.... 2.50

Farandole (Cayeux, 1928). S, French gray and lilac; F, purple-rose....... 10.00

Fascination (Cay., 1927). Pure, clear pink with flowers of enormous size.... 5.00

Grand Monarch (Row., 1929). A velvety bronze-red, bearing many flowers... 7.00

Goldilocks (Wayman, 1930). A large, smooth-textured, uniform soft yellow... 25.00

Gold Top (Salb., 1930). Rich gold; F, red-violet, edged with gold......... 10.00

Gobelin Red (Danenhauer, 1927). This Iris is actually ox-blood red........ 7.50

Grace Sturtevant (Bliss, 1926). Dark reddish-brown and violet-carmine.... 7.00

Henri Riviere (Mil., 1927). S, lemon yellow; F, lilac mauve, yellow reflex... 10.00

Ion (Mead, 1929). S, Bradley's violet; $F$, velvety blue violet.......... 6.00

June Night (Egel., 1930). Large Dauphine blue, with dark zebra-like stripes. . 5.00

King Midas (Mead, 1929). S, golden buff, suffused brown; F, garnet-brown... 15.00

Largo (Ashley, 1930). S, mustard yellow; F, flaring, citron yellow........ 25.00

Lindbergh (Arb. '28). Pansy violet. A superior B. Y. Morrison.......... 3.00

Moon Magic (Shull, 1931). General buff-yellow tone, smooth in texture.. . . 8.00

Melchoir (Wallace, 1927). S, bronzy violet; F, velvety crimson . . . . . . . $\quad 7.50$

Mrs. Valerie West (Bliss, 1925). S, lavender shot with bronze; F, crimson... . 6.50

My Maryland (Sheets, 1930). S, lilac-rose, shaded gold; F, rich red-purple... 25.00

Nene (Cay., 1928). S, Soft, elear lilac; F, vinous red. Gigantic flower....... 10.00

Newtonia (Don., 1929). Amber colored pastel self with frosty irridescence... 5.00

Nocturne (Shull, 1929). S, Dauphin's violet; F, hyacinth violet.......... 5.00

Padre (M. M., 1930). S, yellow-lavender blend; F, rosy-purple flushed blue... 4.00

Pink Satin (J. Sass, 1930). A true pink, glistening texture and satiny sheen.. 23.50

Pluie d'Or (Cay., 1928). A tall and large pure golden yellow of fine form.... $\quad \mathbf{7 . 5 0}$

Pongee (Bret., 1931). Light buff-colored self with frosty irridescence...... 8.00

Rameses (H. Sass, 1928). Crink'ed gold, shaded pink at edge; F, red-pink.... 6.00

Rosakura (Wmsn., 1930). S, rosy-purple; F, rich red-purple. Fine bicolor... 6.50

Rose Marie (Cayeux, 1928). S, red-violet; F, red-purple. New color....... 10.00

Sacramento (M. M., 1929). Giant white plicata, flushed and sanded purple... 9.50

Sir Michael (Yeld, 1925). S, clear, opalescent blue; F, deep purple. Tall.... 5.00

Vert-Galant (Cay., 1929). A brilliant coppery-red, with coppery-fawn S..... 19.50

Wambliska (J. Sass, 1930). The finest tall white produced. Note our price... 12.00

Yves Lassailly (Cay., 1928). A beautiful white and blue combination....... 9.50

Entire collection, valued at $\$ 470.00$, for $\$ 380.00$ 
"The shipment I received from you last year was by far the nicest stock of all that I purchased. Practically every plant bloomed despite the late planting." -Mary E. Thomas, Wichita, Kan.

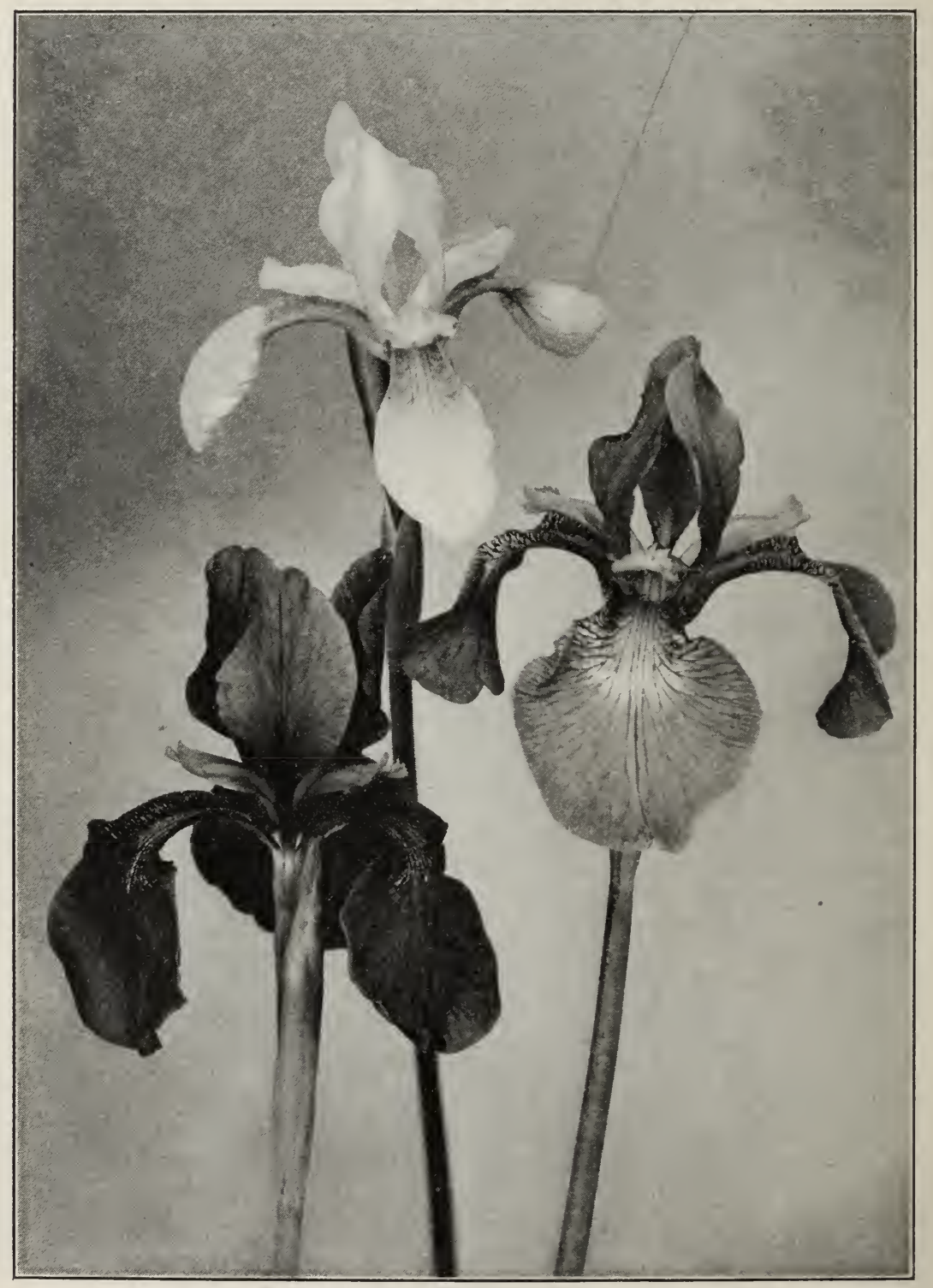

S I B E R I A N I R I S 


\section{IRIS SIBERICA}

The Iris of this group have tall stems and grass-like foliage. They are among the best for cutting or for massing by the waterside. The flowers are various shades of blue, with white or yellow markings, and pure white. The plants do well in wet ground, but are easily grown in any soil.

Blue Flame. The lightest blue Siberian and very striking $\ldots \ldots \ldots \ldots \ldots \ldots 2.00$

Blue Heron. A large, wide-petaled flower or brilliant blue ............ 1.00

Blue Owl. An exquisite rich blue with brouze and white throat......... 1.00

Blue Star. A large, deep rich violet. The stigmas are large and drooping, giving

the flower the appearance of a six-pointed star................... 1.00

Butterfly. The standards and styles are a soft uniform sky-blue........ .50

Emperor. The finest of the real dark Siberians. Very tall ........... .50

Mrs. Sanders. A fine rich brilliant violet-blue of fine form . . . . . . . $\ldots$

Perry's Blue. Beautiful bright sky-blue. Lovely and unusual. . . . . . . 50

Periwinkle. Larger, taller and darker than Perry's Blue. Fine........... 1.00

Red Emperor. Like Emperor but wine red, veined and shaded with blue...... 1.00

Red Raider. A brilliant rose-red lined deeper. Extremely large and tall ...... 1.00

Sanguinea. Intensely brilliant blue flower. Medium height ........... 25

Silver Tip. Dark, clear blue with very light stigmas. Very distinct....... 2.00

Snow Queen. Pure glistening white with yellow throat. Medium height.... .50

Sunnybrook. An exquisite shade of soft Alice blue of fine substance....... . .50

Superba. A more dwarf variety of violet-blue. Fine flower quality . . . . . . 25

True Blue. A fine, beautiful pure blue tinged with yellow on falls........ 1.00

Versicolor Rosea. Small delicate flowers of rose pink, white stamens....... 1.00

Entire collection, valued at $\$ 15.50$, for $\$ 10.00$

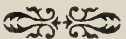

\section{IRIS SPURIA}

These Iris grow in clumps four to five feet high, the fluwers somewhat resembling but larger than the Dutch Iris are borne on a tall stiff stem, well above the blade-like foliage. They do well in any soil, but will thrive in a wet soil in which the Tall Bearded Iris will not grow. This speeies is rapidly increasing in popularity.

Aurea. A fine, uniform rich golden yellow ranked among the best.........\$0.50

Monnieri. A fine, large yellow, similar to but lighter than Aurea......... .50

Mrs. Tait. A fine soft porcelain blue of varying shades............ .75

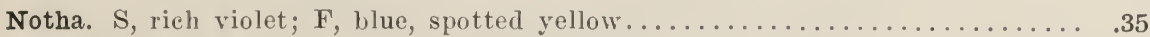

Ochroleuca. White, with orange bloteh on falls. One of the best of the Spurias and should have a place in every garden....................... .50 
"I never received a finer lot of Iris roots from anyone, and $I$ now have more than four hundred varieties."

-Frances Lawton, Thornton, $R$. I.

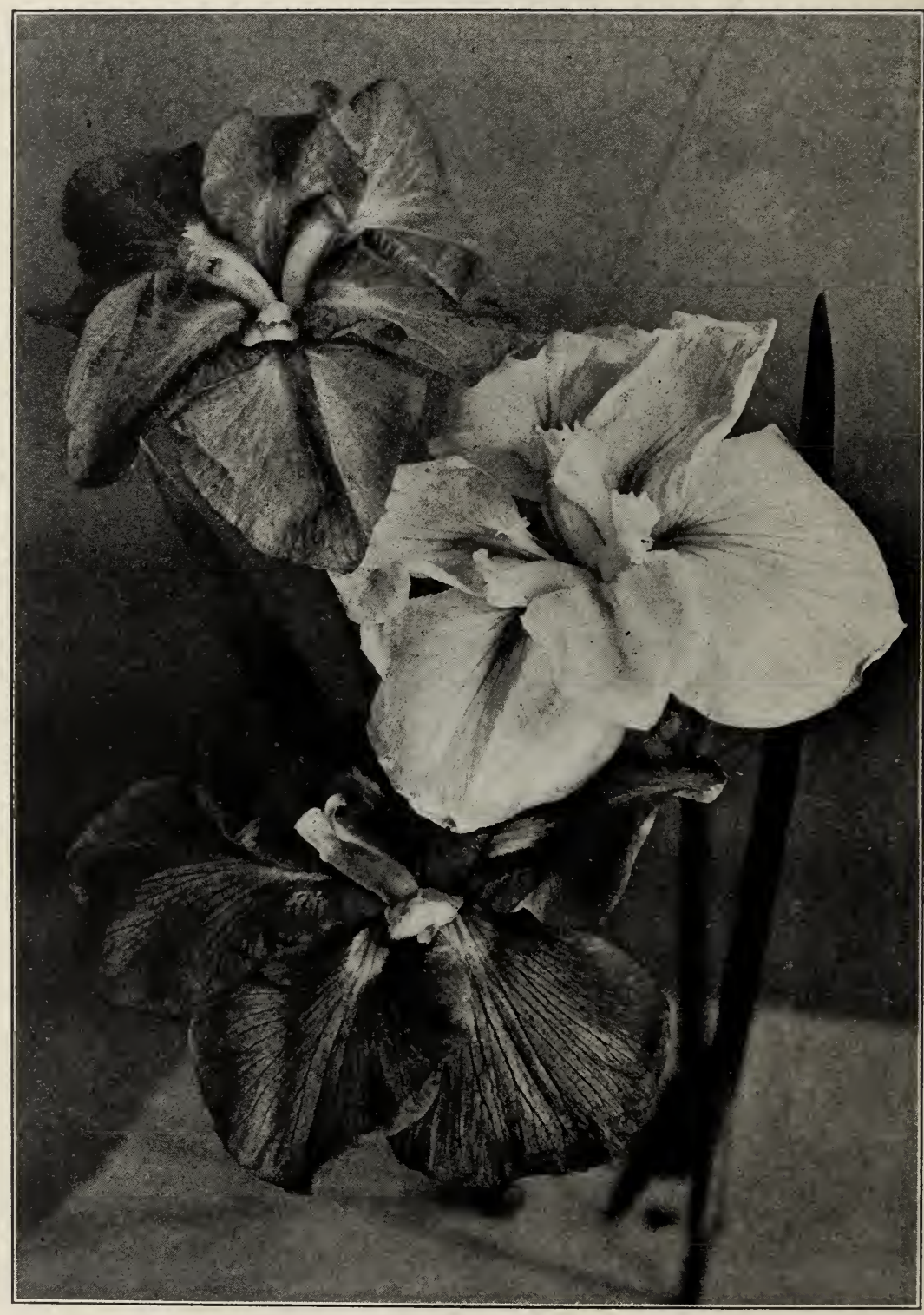

JAPANESE IRIS

Kumono

Kombarin

Kuro Kumo 
"I have recently received two orders of Iris from your concern and feel it only fitting and proper to inform you that the divisions received were the finest, healthiest, and most substantial I have ever received from any grower." -E. J. Swanson, Des Moines, Ia.

\section{JAPANESE IRIS}

These remarkable Iris are now coming into great popularity as their merits are becoming better known. They bloom after the Bearded Iris and continue blooming for fully six weeks. The single varieties have three petals and the double varieties six.

Japanese Iris require an acid soil to give the best bloom, although they will bloom in any soil. The proper acidity is obtained by applying a small amount of sulphate of ammonia to the soil in which they are planted-a handful to each plant, applied once a year. Use no lime. These Iris grow in practically every state, even in Minnesota. In a few places where they have not succeeded, their failure may be attributed to being planted too late in autumn and thus being heaved out by the frost. Plant either in the fall or early spring. When they are ordered with Bearded Iris, we hold this part of the order until the proper time for planting. While they give larger flowers if well watered, the roots should not stand in water during the winter.

It is to be regretted that most dealers sell "mixed" varieties, this term being used to designate seedlings of unknown value-not one per cent of which are worth planting. We have been perfecting our list of varieties for a number of years and have what we believe to be the best collection of named varieties in this country, if not in the world. We contributed nearly a hundred varieties to the Brooklyn Botanical Test Garden some years ago. Many of these varieties have been returned to us with the names which the Garden recognizes. We desire to have our Japanese Iris as correctly named as our other varieties. When other dealers are as particular, this class will become as popular as the Bearded Iris.

Alice Blue. Dbl. A fine large blue with yellow markings............\$ .50

Angel's Den. Dbl. Fine flower of vinous-purple and a good seller........ .50

Asagire. Dbl. Beautifully variegated with white and blue etchings....... .50

Ayasi. Sgl. White center with wide crimson edge. An attractive Iris...... .50

Cloud Dress. Dbl. Grey ground with prominent purple lines radiating ...... $\quad .50$

Doji. Dbl. A beautiful light white, overlaid with deep lavender........ $\quad .75$

Gold Bound. Dbl. A large, pure snow white, with a beautiful gold bar...... $\quad .75$

Harmony. Sgl. Oxide-blue, veined and edged with lilac-pink.......... 1.50

Hatsuki. Sgl. Uniform purple-blue. Very attractive flowers......... .50

Himono. Sgl. Very dark eerise, style branches white, erested purple...... $\quad .50$

Horen. Sgl. White with large orange blotch radiating into white....... $\quad .75$

Hosokawa. Dbl. Purple-blue, with white lines radiating from gold bar..... $\quad .50$

Hotari. Sgl. Beautiful light lavender, veined with purple........... 75

Josephine Heywood. Sgl. Bright blue, with a vivid purple sheen......... $\quad .75$

Kagarabi. Sgl. A fine light lavender, veined with red-purple......... $\quad .50$

Kasugano. Dbl. Plum-purple, with dark pencilings radiating.......... .50

Koko-No-Iro. Dbl. Fine large red-purple with prominent orange bloteh..... $\quad .50$

Komachi. Dbl. A deep violet-purple variety of great beauty.......... $\quad .50$

Kombarin. Dbl. A fine large early pure white which is quite outstanding... $\quad .50$

Koyka. Dbl. A fine dark purple-blue splashed with lavender........... 
"Ihe Iris I ordered from you arrived yesterday in excellent condition."

Kumono. Dbl. Lavender veined white, with yellow central shadings........\$0.50

Kuro Kumo. Dbl. Deep purple, overlaid with blue............... .50

Neptune. Sgl. A beautiful dark blue with large orange bloteh......... .75

Paragon. Sgl. A beautiful large flower of deep purple............. 50

Patrocle. Dbl. A large deep blue with a reddish east.............. 5.50

Prosperpine. Sgl. Light blue ground, veined deeper. Large gold bar........ .50

Reine Helene. Sgl. Blue ground, veined white with large orange bar...... .50

Rinpoo. Dbl. Veined and splashed pink-lavender on white ground........ 50

Rishono. Dbl. Red-purple, overlaid with brilliant blue............. 50

Shadow. Sgl. A large dark red-purple flower with gold bar.......... .75

Shiga. Dbl. Reddish-blue with very large petals. Very fine.......... .50

Shimoyo. Sgl. Beautifully veined on a greyish ground.............. 50

Shoryui. Sgl. White ground, shaded and overlaid with purple-blue........ .50

Triumph. Sgl. Lavender, veined with rich dark purple............ 50

Wakamu. Dbl. Bright erimson-purple, splashed with white.......... .50

Entire collection, valued at $\$ 20.25$, for $\$ 16.00$

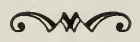

\section{PALESTINE IRIS}

This group includes the Oncocyclus and Regelia species, the Regelia-cyclus hybride resulting from crossing the two species, the Pogo-Regelia hybrids resulting from crossing Regelia varieties with the tall bearded Pogoniris, and the Pogo-eyclus hybrids resulting from erossing the Oncocyclus varieties with the tall bearded species. All the Iris in this group are early and bloom three weeks before the tall bearded varieties. The hybrids are very hardy, as are the Regelias.

The Oncocyclus are too tender for most sections so we are not listing them. The Regelias are natives of Turkestan and Armenia. Their flowers are more slender and delicate, the stalk carrying two to three blooms. The hybrids resulting from various crosses combine the good characteristics of both parent species and are very distinctive and beautiful. A garden is incomplete without a few of these wonderful flowers.

An important requirement in the growing of the Regelia and Regelia-cyclus varieties is to keep all moisture from them during the summer months. In sections where rain falls, they may be lifted and stored in dry soil for the summer and replanted in the fall. Some growers plant in pots and store the pots after blooming. These requirements are not necessary for the Pogo-Regelia and Pogo-cyclus varieties. A well-drained lime soil is best for all. 


\section{REGELIA}

Hoogiana. An Iris noted for a wonderful smoothness of texture. A rery lovely, uniform, bright lavender-blue flower with a conspicuous yellow erest and bright orange beard. One of the rery best Irises............... $\$ 1.50$

Korolkowi Concolor. Enamel pinkish lilac of unusual tone and texture.... 1.50

Stolinifera. An exceedingly handsome Iris of elongated form with crinkly brown edges having a blue-violet center and lighter blue beard.........

Vaga. Large flowers of pale blue lined with bronze and brown...........

\section{REGELIA-CYCLUS}

Beatrix. S, suffused lavender and veined a deeper shade; $F$, heavily veined and dotted lavender on a gray ground, dark velvet bloteh and beard....

Charon. Beantifully reined with old gold and brown on a mahogany ground.

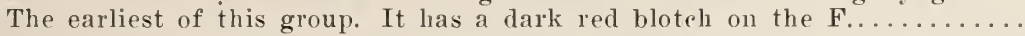

Hebe. Similar to Beatrix, but with darker falls. It is a more vigorous variety and one of the most rapid to multiply. Violet, heavily veined black.....

Hecate. Silky S of uniform smoky rose, covered with a network of darker veins. $\mathrm{F}$, rich mahogany veining over a cream ground, witl a dark spot in

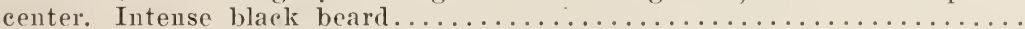

Hera. A most distinet variety with bright ruby red $\mathrm{S}$, beautifully veined. $\mathrm{F}$,

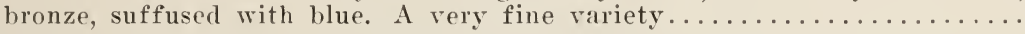

Orestes. S, coppery bronze; F, einnamon hronzed. Beautiful dark red with crinkly edges, greenish-yellow beard, and blue-violet stamens, growing 18

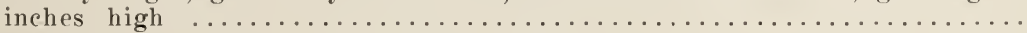

Saturnus. S and $\mathrm{F}$, dotted and veined lavender on a gray ground. Characteris-

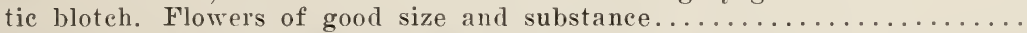

Turkoman. S, warm reddish-brown shot with violet; $F$, ruby-purple with vivid

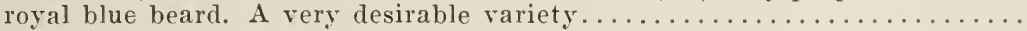

\section{POGO-REGELIA}

Bellorio. A free-blooming variety, bearing slender, graceful flowers of lavender

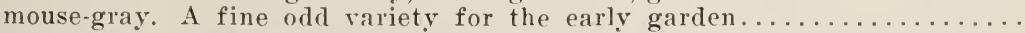

Carmelo. Neither large nor tall, but its growtl, slender foliage and stems, and long, narrow flowers of an unusual shade of blue, put it in a new class, one

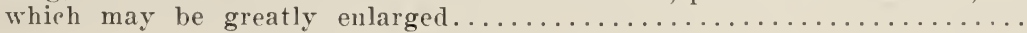

\section{POGO.CYCLUS}

Dilkush. S, heavily veined violet: $F$, deep reddish-purple with black throat

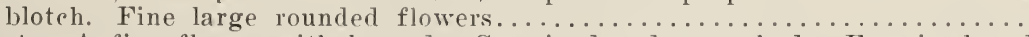

Flecta. A fine flower with lavender S, veined a deeper shade; F, veined and dotted reddish-brown on a creamy-gray ground. Golden beard..............

Hamadan. Upright open ruffled $S$ of uniform rich violet and flaring $F$ the same color, with a white throat orerlaid with purple veins. Styles are rich

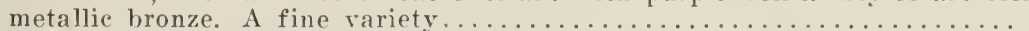

Ib-Pall. A fine free flowering variety, with ruffled reddish-lilae $s$ and dark violet $\mathrm{F}$ over a white ground. Bronzy-yellow beard, with a dark spot on the

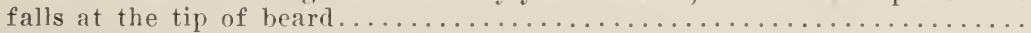

Lady Lilford. S, purple-riolet; $F$, black-purple with a black beard. A large

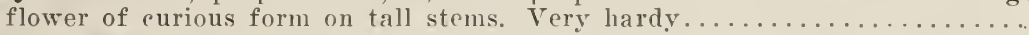

William Mohr. The ground color is pale lilac, s flushed darker. The entire flower is beautifully veined manganese-violet. Substance and shape is of the very best, the flowers being enormous. Four flowers to a stalk. Free flowering and hardy. The outstanding variety among the hybrids........

Zwannenburg. A very large flowered variety, a prodigious bloomer and one of the most rugged of all Iris. S, eream flushed and lightly blotched pale violet and of silky texture. F, smooth velvety old gold splashed maroon. Lemon-yellow erests and bright orange beard. First to bloom............

Entire collection, valued at $\$ 26.75$, for $\$ 20.00$ 
"The only complaint that I can make regarding your Peony roots is that some were so large that $I$ thought it best to divide them, thus making more work planting than $I$ had expected."
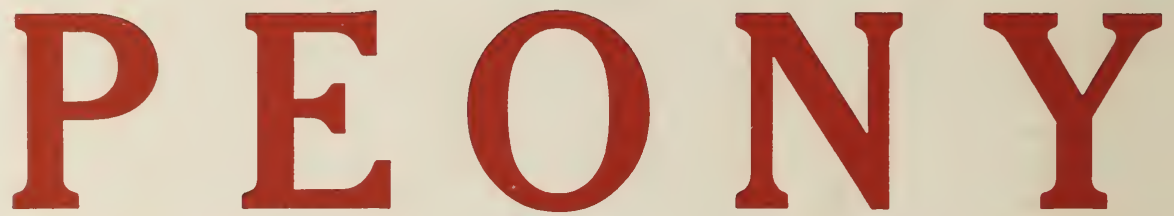

\section{We are disposing of our large stock of peonies at the following low bargain prices, so that we may devote our entire time to Iris. To give our customers}

Our specialization in Peonies began in 1912 with the purchase of the largest collection then in the West, and its removal to Beaverton. We have more than 400 varieties growing in our gardens but are listing only those of recognized merit now retailing at reasonable prices. If you desire any varieties not listed in this catalog, we shall be glad to quote you a price, tor we have them growing in the field. If you will compare these prices with the prices of other dealers, you will realize justı how low they are. Also, bear in mind that we prepay postage and make prompt shipment after the middle of September, which is as early as a Peony should be moved. We have shipped to all parts of the United States with satisfactory results.

Our Peonies begin flowering in May and continue through June. If you have never seen them in bloom, mere words cannot describe their beauty to you, for they make a great bouquet of pink, white and red with all the various shades between. Last year we had 20,000 visitors and we trust that you will be one of that number to visit our gardens this year. We give a large, well-balanced root of 3 to 7 eyes, having been grown in rich clay soil. Anyone dissatisfied witl plants they receive from us may have their money refunded with the return of unsatisfactory roots.

\section{Cultural Directions}

Plant in ordinary soil, first spading the ground well and then planting so that the eyes will be covered with two inches of dirt. Too deep planting results in blind shoots, whi'e exposed eyes result in weak flowers. Plant in full sunlight, away from the roots of trees or shrubs.

Do not fertilize with barnyard manure or other fertilizer rich in nitrogen. Peonies need acid phosphate to produce flowers and potash in order to give strength to the stems. Bone meal is the ideal fertilizer for this purpose. Apply in the fall or early spring for the ingredients are not immediately available for plant food. Scatter the fertilizer around each plant-about a handful to a plant-before the working of the soil each year. The dirt around the plants should be kept well stirred in order to retain the soil moisture.

\section{Peonies as Cut Flowers}

Peonies will last as cut flowers from a few hours to two weeks. When cut in the field after being fully open and especially cut in the middle of the day, they last but two to three hours. But cut in bud early in the morning or late in the evening and then placed in water in a cool place, the blooms will last for several days. We keep the Reine Hortense variety two weeks in this way. 
"The Peonies which I ordered from you came in good shape, and I want to tell you how pleased
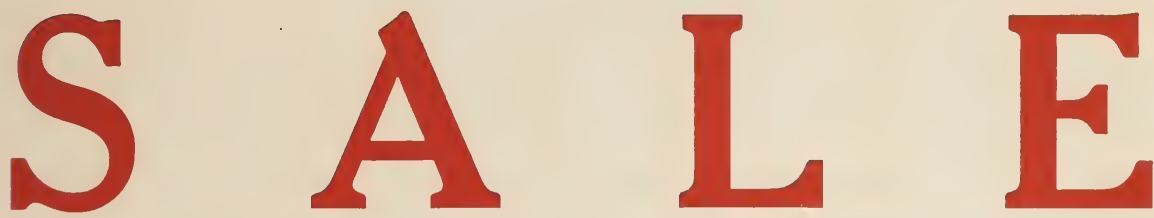

basis of comparison, we are placing the prices of large eastern growers in parenthesis before our own low figures. Select plants now at these bargain prices.

\section{SINGLE PEONIES}

The single varieties are becoming more popular as they become better known. They are more early and very attractive, having a single row of petals with a center of yellow stamens. In the early morning and at dusk the flowers are closed, resembling large rosebuds, and are especially alluring. They keep well as eut flowers.

Catherine Fox. (Ber.) The most beautiful deep rose pink single.........\$ 3.00

Celeste Brochet. (Bro.) White petals dotted lilac, pink effect...... $\$ 3.50) \quad 2.50$

Dreadnaught. (Barr.) A fine, shining, brilliant crimson........... 1.00

Hesperus. (Kel.) A fine deep shell-pink of good substance......... (2.00) 1.00

La Fraicheur. (Des.) A rosy-white which shows up well ........... 2.00

L'Etincelante. (Des.) Brilliant earmine with a silvery border...... (2.00) 1.50

Madeline Gauthier. (Des.) A beautiful silvery flesh pink......... (3.00) 2.00

Meteor. (Kel.) A large flower of bright dazzling erimson............ 1.50

Minerve. (Des.) A beautiful pink, slightly tinted with earmine.......... 1.00

Mrs. Beerbohm Tree. (Kel.) A fine blush white of good substance....... 1.00

Othello. (Des.) Flowers of elear carmine, changing to purple........ (2.00) 1.00

Perle Blanche. (Des.) Petals are pure white with golden stamens.....(4.00) 2.50

Perle Rose. (Kel.) Clear China pink, bordered with silver......... (2.50) 2.00

Pure Love. (Kel.) A very fine pure milk white................ 2.50) 2.00

Stanley. (Kel.) Brilliant red with large golden eenter........... (2.00) 1.00

The Bride. (Des.) Large white flowers with large eenter of stamens. ( 2.00) 1.50

Veloutine. (Des.) Tyrian purple-red with fine velvety reflex....... (1.50) 1.00

Venise. (Des.) Clear pink petals, tinted with carmine........... 1.50) 1.50

Whitleyi Major. Blush white, with several flowers to a stem....... (2.00) 1.50

Entire collection, valued at $\$ 30.50$, for $\$ 20.00$ 
"I want to thank you for the fine plants you sent on my order. They certainly arrived in A-1 condition."

-E. H. Sibley, Wethersfield, Conn.

\section{JAPANESE PEONIES}

These have two rows of guard petals, with stamens transformed into narrow petaloids without pollen. The flowers are entirely different from the double varieties. Their distinctive beauty makes them a desirable asset to any garden.

Alma. (Sh.) Beautiful pale pink guards, enclosing yellow petaloids..(\$5.00) $\$ 2.00$ Ama No Sode. Exceptionally large rose-pink flowers............ 8.00) 4.00 Attraction. (Hol.) Guards deep Tyrian rose, center tipped yellow.... (1.50) 1.00 Cascade. A fine pure snow white, somewhat resembling a water lily..( 3.00$) \quad 1.00$ Crystal Queen. A beautiful large white of fine form and substance... ( 1.00$) \quad 1.00$ Eileen Kelway. (Kel.) White, with long narrow petaloids............. 1.00 Flamboyant. Soft rose color, with attractive rich yellow center.......... 1.50

Geraldine. (Kel.) Deep carmine violet. A fine flower............... 1.00

Gold Mine. (Hol.) Deep, vinous-red petals with golden stamens...... (3.00) 2.00

Ho Gioku. Fine pure white, with sulphur yellow petaloids........... 3.00

Innocence. (Hol.) Lilac-rose flower with canary yellow petaloids......... 2.00

Kumagoe. Deep carmine pink, greatly striated with white........ (1.50) 1.00

Lobolas. Dark erimson flower with petaloids tipped with yellow......... 1.00

Neptune. A fine large flower of beautiful shell pink............. 1.00

Ohirama. Carmine petals, slightly tinged with purple........... (4.00) 2.50

Saturn. A fine rosy-white, one of the very best of its color.......... 2.00

Seiru Somae. Milk-white flower with petaloids sulphur-white...... (2.00) 1.50

Snowdrift. (Wal.) Pure white petals with canary yellow center......... 2.00

Snow Wheel. Immaculate white with a large yellow center......... (5.00) 2.50

Takadorama. A beautiful semi-double of satin-white coloring ......... 1.50

Titian. The finest Japanese of soft lilac pink coloring ............. 1.00

Tokio. A very large clear rose-pink and rated one of the best...... (5.00) 2.50

Vesta. A large purple-red of vigorous growth................. 2.00

Vestucius. Pale lilac-rose with narrow stamenoids................ 1.00

White Swan. (Pl.) A beautiful and attractive magnolia-white....... ( 3.00$) \quad 2.50$

Entire collection, valued at $\$ 43.50$, for $\$ 30.00$

\section{DOUBLE FLOWERING PEONIES}

Addielanchea. (Br.) Large, flat flowers of creamy white......... $\$ 5.00) \$ 2.50$ Albatre. (Cr.) A fragrant, large, blush-white of fine wavy texture...( 1.00) 75

Alexandriana. (Cal.) Large early flower of light violet rose . . . . . . . . 1.00

Alsace Lorraine. (Lem.) A large creamy-white passing to yellow .... (2.00) 1.00

Avalanche. (Cr.) Milk-white, shaded ivory, with center tinged lilac..( 1.50) $\quad .50$

Aviateur Reymond. (Des.) Bright cherry-red, shaded garnet........ (2.00) 1.50

Bayadere. (Lem.) Creamy-white giving a distinct water lily effect..( 3.50$) 2.00$

Beauty's Mask. (Hol.) Large and compact, of clear bluish-white..... ( 1.50) 1.00

Beaute de Villecante. Fine pink blooms on very floriferous plants....... .50 
"The Peonies which I ordered from you came in good shape, and I want to tell you how pleased I am with them." -Mrs. C. S. Howard, Shelton, Wash.

Boule de Neige. (Cal.) A ball of snow with center flecked crimson..(\$1.00) $\$ 0.50$ Chestine Gowdy. (Br.) Late shell pink with a pleasing cream collar..( 2.00) 1.00 Claire Dubois. (Cal.) A satiny pink, slightly tipped silvery-white...( 1.50$) \quad 1.00$ Couronne d'Or. (Cal.) Pure white, with a ring of yellow stamens..... ( 1.00$) \quad .50$ Crown on Crown. Three layers of different shades of pink petals . . . ( 1.00$) \quad .50$ Duc de wellington. (Cal.) White guard petals with sulphur center....... .50 Duchesse de Nemours. (Cal.) Early pure white with sulphur collar...( 1.00$) \quad .50$ Edulis Superba. (Lem.) Very early deep rose pink, crimson markings..( 1.00$) \quad .50$ E. J. Shaylor. (Sh.) Clear silvery-pink, stamenoids edged gold ....... 7.50$) \quad 5.00$ Esther. (Terry) Light rose and eream, flower of Anemone type........ 1.00 Etta. (Terry) Fine large fowers of deep shell-pink, late to bloom..... (1.50) 1.00 Eugenie Verdier. (Cal.) Pale hydrangea-pink with center flecked red..( 1.00$) \quad .50$ Evening Glow. (Hol.) A good hydrangea-pink, tipped with white...( 2.50) 1.00 Expo. Universalle. (Cal.) Fine violet-rose, with silvery reflex.......... .50 Evangeline. (Lem.) Pale lilac rose, splashed with scarlet.......... (1.50) 1.00 Faribault. (Br.) Deep rose with silvery sheen, collar lighter....... (1.50) $\quad .75$

Felix Crousse. (Cr.) A free blooming rose red. Tall and fragrant......... 1.00

Festiva Maxima. (Meillez) Pure white with carmine flakes on edges..( 1.00$) \quad$.75

Floral Treasure. A beautiful free flowering pale lilac-rose............ .50

Fraicheur. (Lem.) Creany white, with delicately tinted guard petals..( 1.50$) \quad 1.00$

Germaine Bigot. (Des.) A clear rose-pink with lighter center........ (1.50) 1.00

Gismonda. (Cr.) A late flesh color, with delicate rose center......... (1.50) 1.00

Gloria Patria. (Foul.) Beautiful shade of pink, shaded violet.......... 1.00

Glory of Sommerset. (Kel.) Fine violet-rose, with eream collar..... . .75) $\quad .50$

Golden Harvest. (Ros.) Guards pale lilac and creamy-white center........ .50

Grandiflora Nivea Plena. (Lem.) A fine early milk-white......... (1.50) $\quad .75$

H. A. Hagen. (Rich.) A deep rose-pink of a fresh, bright color . . . . . ( 3.50) 1.50

Helen Wolaver. (Br.) A late, deep shell-pink of fine form.......... (2.00) 1.00

Hercules. (Terry) Soft rose pink, slightly shaded with white.......... .75

John Richardson. (Rich.) Compact and flat flower of pale lilac rose..( 1.50$) \quad \mathbf{1 . 0 0}$

Jubilee. (Pl.) Very large and flat ivory-white flowers........... (2.00) 1.00

Lady Iris. (Pl.) A fine white, greatly suffused with lake.......... (2.00) 1.00

Lafayette. (Des.) Rose type of flower of dark carmine purple...... ( 1.50$) \quad 1.00$

La Fiancee. (Lem.) Pure white, with center flecked with erimson.......... 1.50

La Roseiere. (Cr.) Pure white, shading to eream at the center...... (1.00) $\quad .50$

La Tendresse. (Cr.) Milk-white, slightly splashed with erimson..... ( 1.00$) \quad .50$

Le Moine Lewis. (Lew.) A fine full double of elear pink ............. 1.50

Lora Dexheimer. (Br.) Intense crimson blossom, darker at the base...( 2.50) 1.50

Louis Van Houtte. (Cal.) A bright red which is a great favorite......... .50

Lucy E. Hollis. (Hol.) Violet-white, with center pale lilac-rose.... ( 1.50) $\quad .75$

Mme. B. Deschamps. (Cal.) Beautiful soft rose with silvery reflex....( .75) $\quad .50$

Mme. Calot. (Miel.) Early shell-pink with collar tinted silver..... ( 1.00$) \quad .75$

Mme. Crousse. (Cr.) Large white flower with eenter flecked red ....( 1.00$) \quad .50$ 
"The Peonies arrived in fine condition and are splendid roots."

-Mrs. W. L. McLaughlin, Chappaqua, N. Y.

Mme. de Verneville. (Cr.) Large pure white with carmine flecks....(\$1.00) $\$ 0.50$

Mme. Emile Galle. (Cr.) Large, compact, flat pink flowers....... 1.00) $\quad .50$

Mme. Forel. (Cr.) Late violet-rose, with center tipped with silver....... 1.00

Mme. Jules Calot. (Cal.) Lilac-white with carmine flecks in center........ $\quad .50$

Mme. Mechin. (Mech.) Deep erimson-garnet, making a fine flower........ $\quad .75$

Mlle. Leonie Calot. (Cal.) Rose type flower of salmon pink........ (1.00) 75

Marcelle Dessert. (Des.) Milk-white, liberally splashed carmine.... (1.50) 1.00

Marie. (Cal.) Late lilac-white, fading to milk-white............ 1.00) $\mathbf{. 7 5}$

Marie Deroux. (Cr.) Pale lilac-rose with salmon shadings........... .50

Marie Jacquin. (Ver.) Rose-white, fading to lilac-white.......... 1.00) $\quad .50$

Marie Lemoine. (Cal.) White with eream center tipped carmine.... (1.00) 50

Mary P. King. (Fr.) Light coral-pink, margined with white....... (3.00) 1.50

Mons. Dupont. (Cal.) Milk-white, splashed with crimson........ (1.00) 75

Mons. Jules Elie. (Cr.) Immense globular blooms of medium pink....... 1.50

Moses Hull. (Br.) A fine dark shell-pink of good texture.......... (1.50) 1.00

Mountebank. (Kel.) A milk-white with center amber yellow........... 1.00

Mrs. A. G. Ruggles. (Br.) A fine delicate, rich, satiny pink....... (3.00) 1.50

Mrs. Charles Gilbert. (Sh.) Large, rather loose pink flower....... (5.00) 2.00

Octavie Demay. (Cal.) An early pale pink and white blend.......... 1.50) 1.00

Officinalis Rubra. The old-fashioned very early blooming red...... (1.00) $\quad .50$

Pasteur. (Cr.) Large flowers of very delicate shell pink......... (1.50) 1.00

Perfection. (Rich.) Delicate shell pink or lilac-white. Fragrant...... (1.00) $\quad .50$

Philomele. (Cal.) Guards violet rose; center creamy-yellow ....... (1.00) $\quad .50$

Ponemah. (Fr.) Pink, shading lighter at edge of petals............ 1.00

Pottsi Alba. (Buyek) A fine flower of beautiful light pink........... 1.00

President Roosevelt. (War.) A fine, deep, brilliant red............. 1.00

Pride of Essex. (Th.) Broad petals of deep flesh pink........... ( 5.00) 3.00

Princess of Wales. (Kel.) Late pale lilac-rose, guards flecked red......... 1.50

Rachel. (Terry) Bright garnet-red, shaded darker ruby-red ....... 1 1.00) $\quad .50$

Reine Hortense. (Cal.) One of the best uniform hydrangea-pinks........ 2.50

Sarah Bernhardt. (Lem.) A beautiful late soft pink, tipped silver...( 2.50) 2.00

Secretary Fewkes. (Sh.) Creamy-white, with slightly lighter center..( 6.00) 2.50

Solfatare. (Cal.) Milk-white guards and sulphur collar............ 50

Souvenir de Francois Ruitton. (Riv.) Brilliant cherry-pink......... 2.50) 2.00

Splendida. (Kel.) Large flesh-white blooms, tinged with lilac....... (3.00) 1.00

Suzette. (Des.) Fine flower of bengal-rose, tinted carmine........ 2.00) 1.50

Victorie de la Marne. (Des.) Amaranth-red with silvery reflex....... (5.00) 2.50

Virginie. (Cal.) A fine light pink of very good form ........... 1.00) $\quad .50$

Welcome Guest. (Hol.) Bright silvery-rose fading to rose-white..... (1.00) 50

Wiesbaden. (G. and K.) Light rose intermingled with golden stamens..( 3.00$) \quad 1.50$

William Penn. (Br.) Gigantic fragrant flowers of light rose........... 1.00

Winnekenni. (Th.) A fine, large, beautiful late cherry-pink........... 1.00

Entire collection, valued at $\$ 96.75$, for $\$ 70.00$ 
"The Peonies were splendid and arrived in perfect condition. The roots were large and the buds big and fat. There may be some fowers next year." -E. O. Essig, Berkeley, Calif.

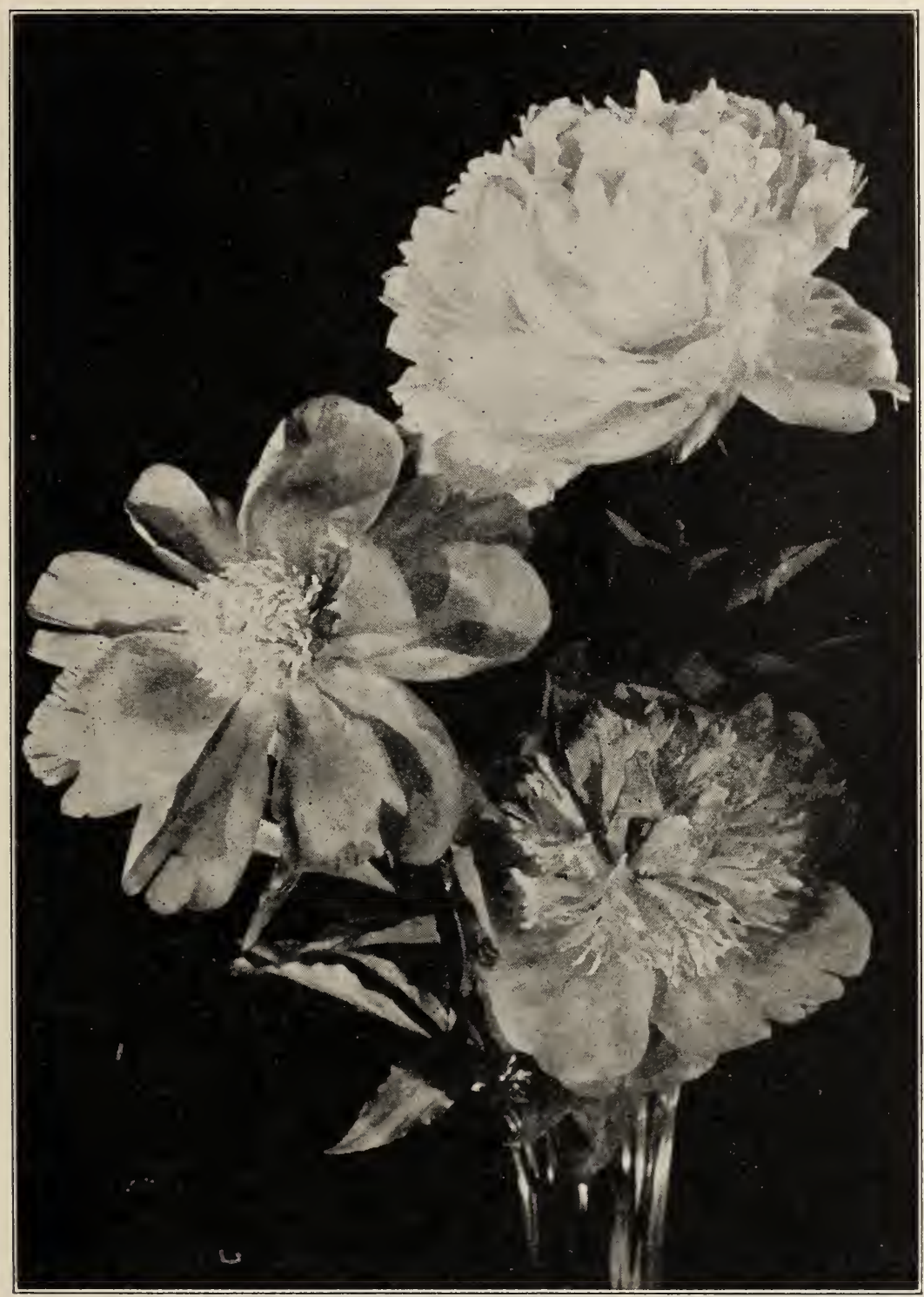

PEONY TYPES

Single

Double

Japanese 
"The Peony roots sent me were certainly fine and I expect to have some good blooms from them."

- B. G. Huse, Lorain, Ohio.

\section{Try A Peony Collection!}

Realizing that many who desire a selection of peonies may not have the time or inclination to select the proper varieties from our display gardens or eatalog, we give below a number of collections which are truly bargains. They have been selected so as to give the most value for the money. One substitution of a variety of similar price may be made in each collection if desired.

All collections are shipped prepaid.

\section{Collection No. 1}

\section{Long Season of Bloom}

Mme. de Verneville, early white. $\$ .50$

Crown on Crown, early pink..... .50

Officinalis Rubra, early red...... .50

Boule de Neige, midseason white.. .50

Glory of Sommerset, mid. pink... . .50

President Roosevelt, mid. red.... 1.00

Couronne d'Or, late white....... .50

Floral Treasure, late pink...... .50

Rachel, late red........... .50

Value.

$\$ 5.00$

\section{Collection for $\$ 4.00$}

\section{Collection No. 2}

Early Flowering

Duchesse de Nemours, white.....\$ .50

Mme. de Verneville, white...... .50

Octavie Demay, pink......... 1.00

Edulis Superba, pink......... .50

Officinalis Rubra, red......... .50

Felix Crousse, red.......... 1.00

Value............... $\$ 4.00$

Collection for $\$ 3.00$

\section{Collection No. 3}

\section{Midseason Flowering}

Boule de Neige, white........ \$ .50

Mme. Crousse, white......... .50

Mme. Florel, pink.......... 1.00

Moses Hull, pink........... 1.00

Bertha, red ............... .50

Louis Van Houtte, red........ .50

Value............... $\$ 4.00$

Collection for $\$ 3.00$

\section{Collection No. 4}

Late Flowering

Couronne d'Or, white........\$.50

Marie, lilac white........... .75

Helen Wolaver, pink........ 1.00

Floral Treasure, pink........ .50

Rachel, red .............. .50

President Roosevelt, red....... 1.00

Value............... \$4.25

Collection for $\$ 3.00$

\section{Collection No. 5}

\section{Japanese}

Crystal Queen, white........\$1.00

Cascade, white ............ 1.00

Titian, lilac-pink ......... 1.00

Tokio, rose-pink ........... 2.50

Vesta, purple-red ........... 2.00

Value............... $\$ 7.50$

Collection for $\$ 5.00$

Collection No. 6

Single

Hesperus, pink .........\$1.00

Minerve, pink ............ 1.00

Othello, red ............. 1.00

Veloutine, purple-red ........ 1.00

The Bride, white........... 1.50

Mrs. Beerbohm Tree, white..... 1.00

Value.

$\$ 6.50$ 


\section{Collection No. 7}

\section{Finest Mixed}

Hesperus, single, pink....... \$1.00

The Bride, single, white....... 1.50

Veloutine, single, red........ 1.00

Titian, Japanese, pink........ 1.00

Takadorama, Japanese, white.... 1.50

Vesta, Japanese, red......... 2.00

Felix Crousee, double, red....... 1.00

Mrme. Forel, double, pink....... 1.00

La Rosiere, double, white...... .50

Value.

$\$ 10.50$

\section{Collection for $\$ 7.00$}

\section{Collection No. 8}

\section{Prizewinner}

Floweret of Eden, pink...... \$5.00

Pride of Paulding, pink........ 5.00

Victorie de la Marne, red....... 2.50

Felix Crousse, red............ 1.00

Kelway's Glorious, white....... 6.00

Secretary Fewkes, white........ 2.50

Winnikenni, cherry pink....... 1.00

Value.

$\$ 23.00$

\section{Collection for $\$ 17.00$}

Collection No. 9

\section{Bargain}

Couromne d'Or, white........\$.50

Crown on Crown, pink........ .50

Louis Van Houtte, red........ .50

Mrme. de Verneville, white...... .50

Floral Treasure, pink......... .50

Officinalis Rubra, red......... .50

Boule de Neige, white......... .50

Welcome Guest, rose......... . .50

Rachel, red............... .50

Value.

.$\$ 4.50$

\section{Collection No. 10}

Red Varieties, Entire Season

Felix Crousse ............\$1.00

Bertha ................. 50

Louis Van Houtte............ .50

Officinalis Rubra............. .50

Rachel .................... .50

President Roosevelt .......... 1.00

Value.

$\ldots \$ 400$

Collection for $\$ 3.00$

Collection No. 11

Pink Varieties, Entire Season

Floral Treasure .............\$.50

Welcome Guest ............. .50

Glory of Sommerset......... .50

Crown on Crown............ .50

Eugenie Verdier ............. . 50

Expo. Universalle ............ . 50

Beaute de Villecante........... .50

Mme. Emile Galle............. .50

Virginie ................ .50

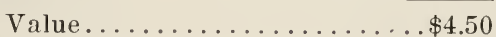

Collection for $\$ 3.00$

Collection No. 12

\section{White Varieties, Entire Season}

Duchesse de Nemours.........\$.50

Mme. de Verneville........... . .50

Boule de Neige............. . .50

Mme. Crousse ............... . .50

Couromne d'Or ............. .50

Golden Harvest ............. . .50

La Rosiere ................. .50

La Tendresse ............... .50

Solfatare ................. 50

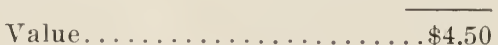

Collection for $\$ 3.00$

Collection for $\$ 3.00$

\section{Oriental Poppies}

Orange Giant, very large, orange..\$ .25

Mahoney, dark malıgany-maroon. .50

Rose Queen, delicate rose pink... 1.00

Royal Scarlet, fine bright red... 1.00

Value.................\$2.75 
"My Iris roots were unusually fine and are doing splendidly. I am enclosing a list of flower lovers who desire your catalog."

\section{OUR RECENT ADDITIONS}

A progressive Iris grower must add new varieties to his collection each year and discard the older originations which have become inferior. In following our policy of adding a number of the outstanding introductions to our collection each season, we have procured the varieties listed below and now have them under observation. Should any of our customers desire deseription or price of any of these Iris, we shall be glad to correspond with them.

Abora (Hill 1931)

Airy Dream (Stur. 1929)

Anne Marie Cayeux (Cay. 1928)

Amber Wave (Murr. 1930)

Athanael (Mill. 1925)

Belle Porter (Lap. 1929)

Blackamoor (Sass. 1931)

Blue Gem (Way. 1931)

Bonita (M. M. 1928)

Brallier Dreadnought, (Bral. 1930)

Brittoness (Dykes 1927)

Bronze Sphynx (Dan. 1929)

Buff (Sass 1929)

Byron Gray (Hud. 1931)

Capt. Courageous (Row. 1929)

Cassandre Cayeux (Cay. 1928)

Cavaleade (Sturt. 1931)

Charis (Nich. 1931)

Columbine (Mur. 1930)

Coral Queen (Way. 1931)

Crucible (Ber. 1929)

Day Dream (Stur. 1925)

Dejah (Perry 1923)

Dog Rose (Insole 1930)

Doxa (Sass 1930)

Edgewood (Hall 1926)

Egypt (Wal. 1929)

Eloise Lapham (Lap. 1930)

Elizabeth Huntington

Elsa (Mor. 1926)

Erebian (Loomis 1930)

Evolution (Cay. 1927)

Flush of Dawn (Ber. 1931)

Fragonard (Cay. 1927)

Francis Gray (Hud. 1931)

Francheville (Cay. 1927)

Frivolite (Cay. 1929)
Golden Crown (Way. 1931)

Gluck (Cay. 1928)

G. P. Baker (Perry 1930)

Grace Wayman (Way. 1931)

Graymist (Grin. 1929)

Hasson (Mur. 1930)

Highlight (Nes. 1928)

Honeydrop (Mor. 1929)

Hollywood (Essig 1929)

Hyperion (Bliss 1921)

Hypnos (Connell 1931)

Iriscrest (Mead 1929)

Jalapa (Mill. 1926)

James Hudelson (Hud. 1930)

J. C. Weld (Ferry. 1923)

Jeannette M. Kennedy (Kel.1931)

Joseph's Coat (Jay 1931)

Kaleidoscope (Jay 1931)

King Juba (Sass 1931)

Lockinvar (Sass 1931)

Lodestar (Hall 1925)

Mary Geddes (Wash. 1930)

Manot Lescant (Dan. 1927)

Manza (Hud. 1931)

Mopsa (Hort. 1924)

Mirasol (M. M. 1929)

Monterey (M. M. 1929)

Mrs. H. M. Hudelson (Hud. 1930)

Mrs. S. M. Hudelson (Hud. 1930)

Mrs. Wicht (Jay 1931)

Naiad Atlanta (Dan. 1927)

Nemo (Cay. 1927)

New Windsor (Hud. 1931)

Numa Roumestan (Cay. 1928)

Nurmahal (Nich. 1931)

Nusku (Nes. 1928)

Orizaba (Berry 1925)

Osprey (Berry 1927)
Paul Veronese (Vilm. 1928)

Peggy Babbington (Mild. 1929)

Pegase (Vilm. 1926)

Penn Treaty (Dan. 1930)

Petral (Mor. 1923)

Phebus (Cay. 1929)

Pirate Gold (Way. 1931)

Rayo de Sol (M. M. 1929)

Redlight (Way. 1931)

Red Robe (Nich. 1931)

Refulgence (Way. 1930)

Rosa Bonheur (Cay. 1928)

Rosa Ring (Hud. 1931)

Rose of Cuba (Sass 1930)

Sachem (Loomis 1930)

San Diego (M. M. 1929)

Sandrine (Cay. 1927)

Sea Dawn (Nich. 1931)

Senlac (Bliss 1929)

Seneca (Ashley 1931)

Shasta (M. M. 1927)

Shogun (Nich. 1931)

Shushan (Foster 1913)

Sister Sue (Hud. 1931)

Spahi (Vilm. 1925)

Spark (Nich. 1931)

Snowcapt (Bales 1927)

Spring Maid (Marriage 1931)

Summer Day (Hardee 1931)

Sun God (Sass 1930)

Sunlight (Stur. 1929)

Tokay (Nich. 1931)

Van Valkenburg (George 1931)

Waconda (Sass 1928)

W. C. Kennedy (Keller 1929)

Winneshiek (Sass)

W. R. Dykes (Dykes 1926)

\section{Neicas}

\section{INDEX}

Ayres Introductions........... 13

Collections of Iris............. 4

Collection, $15 \mathrm{c} \ldots \ldots \ldots \ldots \ldots \ldots 12$

Collection, 25c.............. 10

Double Flowering Peonies.........26

Intermediate Iris ............ 9

Iris Information ............. 2

Japanese Iris ................ 21

Japanese Peonies ............. 26

Kirkland Introductions ........ 13

Miscellaneous Iris ............ 13

New Introductions of Merit....... 17

Order Sheet ............... 11
Oregon Originations .......... 15

Oriental Poppies ............. 31

Palestine Iris ............... 22

Peonies ................... 24

Peony Collections ............. 30

Pogo-Regelia and Pogo-Cyclus...... 23

Recent Iris Additions........... 32

Regelia and Regelia-Cyclus....... 23

Single Peonies .............. 25

Spuria Iris.................. 19

Tall Bearded Iris.............. 5

Wareham Seedlings ........... 15 


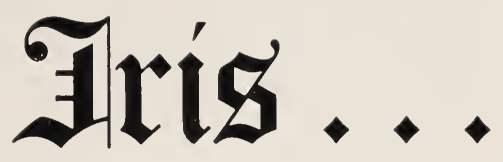

may be planted any month in the year but do best when planted during June, July, August and September

WWHWHWM ORDER NOW

WE HAVE SATISFIED CUSTOMERS IN EVERY STATE 75 per cent of our customers live east of the Mississippi 


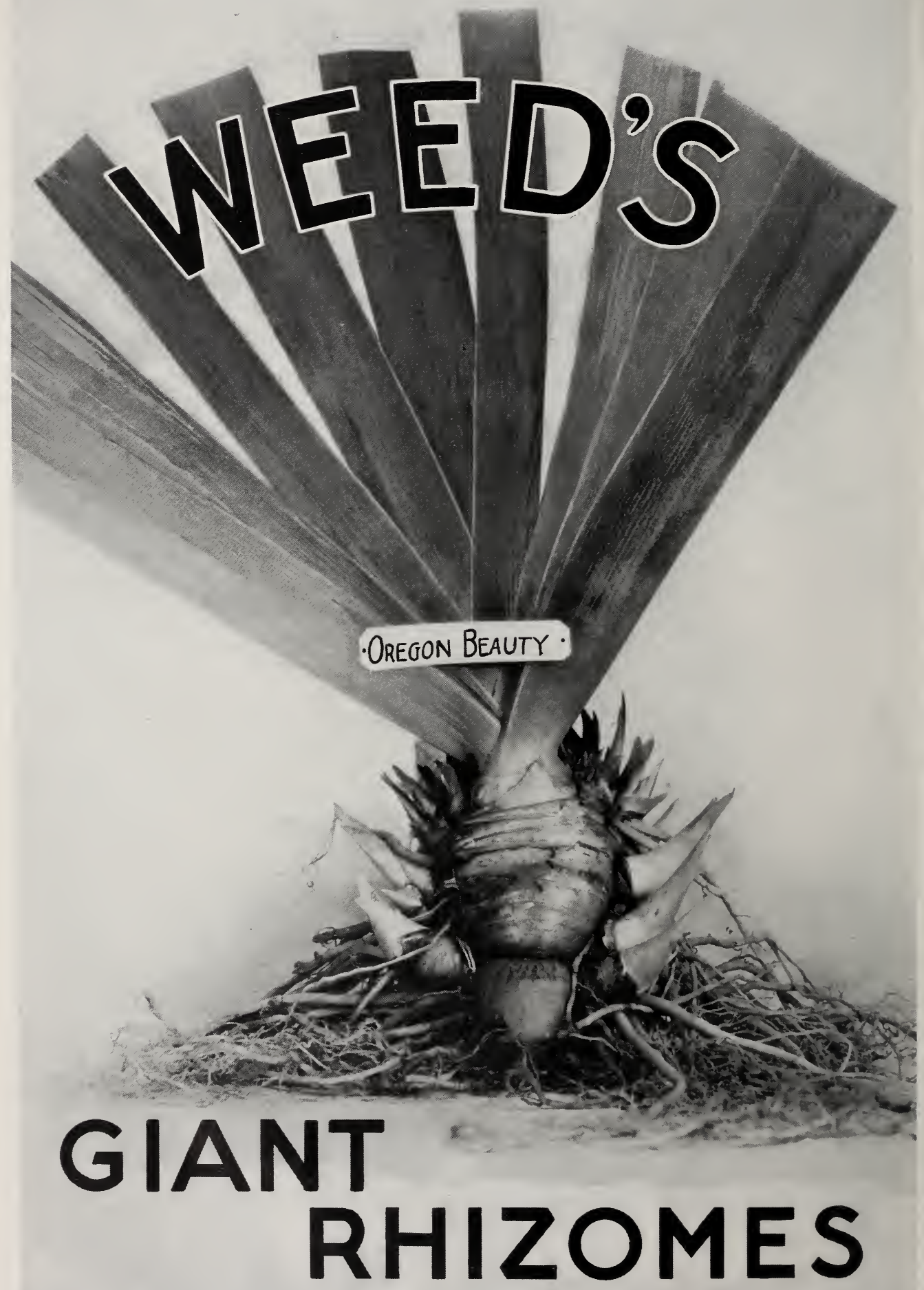

